\title{
Conversion of Plastic Waste into Supports for Nanostructured Heterogeneous Catalysts: Application in Environmental Remediation
}

\author{
Geovânia Cordeiro de Assis ${ }^{1, *}$, Roberta Anjos de Jesus ${ }^{2}$, Wélida Tamires Alves da Silva ${ }^{3}$, \\ Luiz Fernando Romanholo Ferreira ${ }^{2}\left[\right.$, Renan Tavares Figueiredo ${ }^{2}$ and Rodrigo José de Oliveira $3, * \mathbb{C}$ \\ 1 Institute of Chemistry and Biotechnology, Federal University of Alagoas, Maceio 57072-900, Brazil \\ 2 Institute of Technology and Research, Tiradentes University, Aracaju 49032-490, Brazil; \\ robertaanjos.quimica@yahoo.com.br (R.A.d.J.); luiz.fernando@souunit.com.br (L.F.R.F.); \\ lcem@itp.org.br (R.T.F.) \\ 3 Physical Chemistry of Materials Lab, Department of Chemistry, State University of Paraíba, \\ Campina Grande 58429-500, Brazil; welidatamires14@gmail.com \\ * Correspondence: gc.uepb@gmail.com (G.C.d.A.); deoliveirarj@servidor.uepb.edu.br (R.J.d.O.)
}

\section{check for} updates

Citation: de Assis, G.C.; de Jesus, R.A.; da Silva, W.T.A.; Ferreira, L.F.R.; Figueiredo, R.T.; de Oliveira, R.J. Conversion of Plastic Waste into Supports for Nanostructured Heterogeneous Catalysts: Application in Environmental Remediation. Surfaces 2022, 5, 35-66. https://doi.org/10.3390/ surfaces 5010002

Academic Editor: Gaetano Granozzi

Received: 16 November 2021

Accepted: 19 December 2021

Published: 24 December 2021

Publisher's Note: MDPI stays neutral with regard to jurisdictional claims in published maps and institutional affiliations.

Copyright: (C) 2021 by the authors. Licensee MDPI, Basel, Switzerland. This article is an open access article distributed under the terms and conditions of the Creative Commons Attribution (CC BY) license (https:// creativecommons.org/licenses/by/ $4.0 /)$.

\begin{abstract}
Plastics are ubiquitous in our society and are used in many industries, such as packaging, electronics, the automotive industry, and medical and health sectors, and plastic waste is among the types of waste of higher environmental concern. The increase in the amount of plastic waste produced daily has increased environmental problems, such as pollution by micro-plastics, contamination of the food chain, biodiversity degradation and economic losses. The selective and efficient conversion of plastic waste for applications in environmental remediation, such as by obtaining composites, is a strategy of the scientific community for the recovery of plastic waste. The development of polymeric supports for efficient, sustainable, and low-cost heterogeneous catalysts for the treatment of organic/inorganic contaminants is highly desirable yet still a great challenge; this will be the main focus of this work. Common commercial polymers, like polystyrene, polypropylene, polyethylene therephthalate, polyethylene and polyvinyl chloride, are addressed herein, as are their main physicochemical properties, such as molecular mass, degree of crystallinity and others. Additionally, we discuss the environmental and health risks of plastic debris and the main recycling technologies as well as their issues and environmental impact. The use of nanomaterials raises concerns about toxicity and reinforces the need to apply supports; this means that the recycling of plastics in this way may tackle two issues. Finally, we dissert about the advances in turning plastic waste into support for nanocatalysts for environmental remediation, mainly metal and metal oxide nanoparticles.
\end{abstract}

Keywords: nanoparticles; environmental remediation; supports; heterogeneous catalysts

\section{Introduction}

The consumption of plastic materials is vast and has been growing continuously due to the advantages derived from its versatility. These advantages include the relatively low cost of plastic and its durability, which is due to its high chemical stability and low degradability [1-3]. The most-used plastics come from synthetic polymers represented by polyethylene (PE), polypropylene (PP), polystyrene (PS), poly(ethylene terephthalate) (PET), and poly(vinyl chloride) (PVC) [4]. It is estimated that almost $60 \%$ of solid plastic waste is disposed of in open spaces or landfills around the world due to its large production and consumption in various applications, such as packaging [5], construction [6], electricity and electronics, agriculture and health [7]. Among the anthropogenic waste produced in modern human society, disposable plastics constitute some of the most persistent environmental pollutants [3].

Plastic pollution has become an acute global concern and is a problem that causes adverse socioeconomic and environmental disturbances. Plastic waste, both industrial and 
municipal, represents a major environmental challenge in developing countries [8,9]. In 1972, when the first peer-reviewed investigation into plastic pollution was launched [10], the annual global production of plastics was about 50 million tons; in 2019, the plastics manufactured globally registered an increase of almost 7 times, reaching 368 million tons [11]. A substantial parallel increase in the amount of plastic waste produced globally resulted from this increase in plastics manufacturing [11]. Solid waste management is one of the problematic issues the world is currently facing. Inadequate management of plastic waste does not only contaminate the environment, but also, a substantial amount of waste has no specified use and most is disposed of in sanitary landfills or indiscriminately in inappropriate dumps and drainages (which is the case in most developing countries), posing not only a major threat to the environment and public health, but also a huge loss of economic value [12-18].

In this context, plastic waste has been promising for the field of catalysis, in obtaining supports for catalysts, and especially for nanostructured catalysts [19-21]. Usually, catalysts are applied in suspension in the reaction medium in powder form, which can influence problems such as loss of the catalyst; another problem is that when the catalyst is applied in powder form, the recovery is carried out using traditional methods, such as separation, extraction, filtration, vacuum distillation or centrifugation, which are tedious and timeconsuming processes. Furthermore, they are uneconomical processes and therefore difficult to apply on an industrial scale [22]. These separation processes are generally not able to collect nanostructured catalysts without the loss of dust. Recovery by filtration is not advisable because smaller-sized nanoparticles can pass through the filter [22]. Taking into account that some of the precursors for catalyst synthesis have high prices, alternatives to immobilize and possibly reuse catalysts in consecutive catalytic cycles is an emerging concern. In addition to this inconvenience, when the catalysts are intended to degrade contaminants in water in photocatalytic applications, the suspended catalyst powder can cause turbidity in the reaction medium, making it difficult for light to penetrate into the active sites of the catalyst itself.

The development of catalytic support technologies can lead to a quality of sustainable environmental systems due to a combination of two serious problems: the large amount of plastic waste without proper disposal, and the emerging concern of dangerous contaminants in waterbodies. Therefore, the recovery of plastic waste harmful to the environment applied in the manufacture of new materials for the treatment of water and effluents that contain dangerous contaminants not only provides adequate disposal for waste based on synthetic polymers, but also guarantees treated water with resources of low cost and easy access. It is important to note that in this review we will specifically focus on plastic waste to obtain catalytic supports, but this technology can also be implemented for broader applications, including air purification, deodorization [23] and anti-fouling [24], as will be discussed briefly throughout the text.

\section{Plastic Waste Chemistry}

The etymology of plastic comes from the Greek "plastikós", which defines materials that are easily moldable due to an external action [25]. Chemically, plastics are formed by long chains of macromolecules, or polymers, and other substances that, when added, optimize the processability and stability of the final product. Due to their nature, plastics have unique properties that make them attractive compared to other materials: they are light, have mechanical and corrosion resistance, are easy to process, are low cost, and have good chemical and biological stability [26].

Although there are numerous classification schemes, from a technological point of view, plastics can be divided into four basic categories [27]:

(I). Natural: provide the mechanical foundation for most plants and animals, as do carbohydrates and proteins. Examples of these are biodegradable materials;

(II). Elastomers: have elastic properties, which recover their initial length after tension interruption. Examples of these are tires; 
(III). Thermosets: these are plastics that, during manufacture, are moldable at low temperatures and harden when heated, typically via chemical crosslinking reactions. Thus, when heated, they are not recyclable. For this reason, they possess excellent mechanical properties, namely dimensional stability, rigidity, and non-ductility, among others. Examples of these materials are formaldehyde and epoxy resins, among others;

(IV). Thermoplastics: formed by macromolecules. Their main characteristic is that when heated, intermolecular forces are weakened, making them malleable, and when cooled, they solidify. This process is reversible, and this is their main advantage. Most plastics produced today are thermoplastics. There are different types of plastics based on their constituent groups and the type of materials used in their production.

In this context, this topic will address the theoretical foundation of the five main types of thermoplastics and their corresponding physicochemical properties that represent a major challenge from the environmental impact and health perspectives. The environmental aspects associated with the use of these materials will be listed in topic 3 .

\subsection{Types}

\subsubsection{Polyethylene (PE)}

PE is the most-used plastic worldwide due to its simple chemical structure (see Table 1), making it very easy and cheap to process. It is a tenacious thermoplastic, obtained by the polymerization of ethylene [28].

The main characteristics of this plastic are its low cost, chemical resistance, low friction coefficient, non-toxicity, odorlessness, ease of processing, and low water permeability. Polyethylene containers are commonly used in food packaging because they pose no health risks, as they do not contain harmful additives to the human body, although some studies have shown that prolonged exposure of plastics to sunlight can make them harmful [29]. PE is available in low-density PE (LDPE) and high-density PE (HDPE) forms. LDPE has long side-chain ramifications in its structure, making it less dense and crystalline, so these plastics are more flexible than PE. HDPE, on the other hand, has no branching, making it highly dense [30]. Unfortunately, this type of plastic is very difficult to recycle, as discussed in Section 3.

\subsubsection{Polypropylene (PP)}

$\mathrm{PP}$ is a polyolefin derived from the polymerization of propylene, and its chemical structure is shown in Table 1. Because of its cost, low density, good flexibility, and resistance to chemicals, abrasion, and moisture, it has excellent processing and performance advantages [31,32]. Thus, this plastic is a substitute for other materials and is found in a large number of applications, including the production of packaging, cars, appliances, among others, as they do not contain harmful substances, thus being safe for humans.

On the other hand, PP is degraded by the action of ultraviolet light since the radiation energy absorbed by the polymer results in the removal of hydrogen atoms attached to tertiary carbon groups, causing a reduction in molecular weight and modification in the structure chemistry [33].

\subsubsection{Polystyrene (PS)}

PS, whose structure is shown in Table 1, is derived from petroleum, contains benzene and is classified as a human carcinogen according to the International Agency for Research on Cancer. In addition, PS is considered toxic to the brain and nervous system because when heated it can leach out styrene [30].

It is commonly used in the production of insulators and packaging materials due to its versatility, as it has a wide range of desired properties such as rigidity, foamability, low cost, high resistance to acid and bases, transparency, brittleness, opaqueness, flexibility, low density and humidity, high brightness, and good electrical properties. It can be stabilized against ultraviolet radiation and can be made in an expanded foamed form, serving as a thermal insulator $[34,35]$. 


\subsubsection{Poly (Vinyl Chloride) (PVC)}

PVC is obtained from the polymerization of vinyl chloride; Table 1 shows its chemical structure. It is thermally sensitive and considered highly toxic to the environment and public health due to the presence of heavy metals and phthalates, among other additives $[30,36]$. On the other hand, the cost-effectiveness and versatility of PVC make it very popular in the production of consumer goods. It is commonly used in toys, plastic wrap, detergent bottles, medical tubes, and more.

Unplasticized PVC is very rigid, more so than PE and PP. On the other hand, in its plasticized form, there is a modification of the polymer through the addition of lowmolecular weight plasticizers, and the resulting pastic can be highly flexible, to the point that it can mimic the flexibility of natural materials such as leather [37].

\subsubsection{Poly (Ethylene Terephthalate) (PET)}

PET is produced by reacting terephthalic acid with ethylene glycol, as shown in Table 1. It is used in the bi-oriented packaging and film sectors due to its high mechanical resistance, gloss, and transparency. Because PET has good gas and moisture barrier properties, it is used in carbonated beverage bottles. These, however, contain toxic additives, and plastics made from PET must be protected from high temperatures to prevent their leaching. For example, antimony trioxide, which has a high carcinogenic potential in humans, is used as a catalyst in the production of PET [30,36,38].

\subsubsection{Polyethylene/Polypropylene/Polystyrene (PE/PP/PS)}

The most common plastics in current use are poly(ethylene terephthalate) (PET), polystyrene (PS), polypropylene (PP) and polyethylene (PE) [4-6]. The conventional process of recycling polymers often involves the usage of chemical substances, such as compatibilizing agents, since the polymers cannot be blended together [4]. Hence, compatibilizers are essential for the polymer's blending and mixing processes as it might provide better properties [4]. Some additives are designed to stabilize the polymer and make it more resistant towards degradation [39]. PP/PE/PS blends have been researched in the recovery of plastic waste [40-43] and initial results have shown some technical and economical promise.

\subsubsection{Low-Density Polyethylene/Polypropylene (LDPE/PP)}

There are several types of $\mathrm{PE}$, but the most common types are high-density polyethylene (HDPE) and the low-density polyethylene (LDPE) [44]. LDPE is a flexible form of polyethylene with unique flow properties that make it ideal for shaping into a film. It has high ductility but low tensile strength, allowing it to be stretched considerably before breaking. LDPE waste mostly results from bags and packaging films. Owing to its poor mechanical properties and easy processability, it is usually recycled as garbage bags [45]. Polypropylene (PP) has been widely used as packaging material, for instance, as margarine and yogurt containers, bottle caps and microwavable food, due to its desirable physical properties such as high tensile strength, high stiffness and high chemical resistance, The combination of LDPE and PP is frequently found in polymer waste streams. Because of their similar density, PP and LDPE cannot be easily separated from each other in the recycling stream [46]. In general, blends of PE and PP have become a subject of great economic and research interest, not only to improve the processing and mechanical properties of $\mathrm{PP}$, but also to expand opportunities to recycle these mixed plastics [45]. 
Table 1. Types of plastics, chemical structure, and symbology (Miandad et al. 2017) [47].

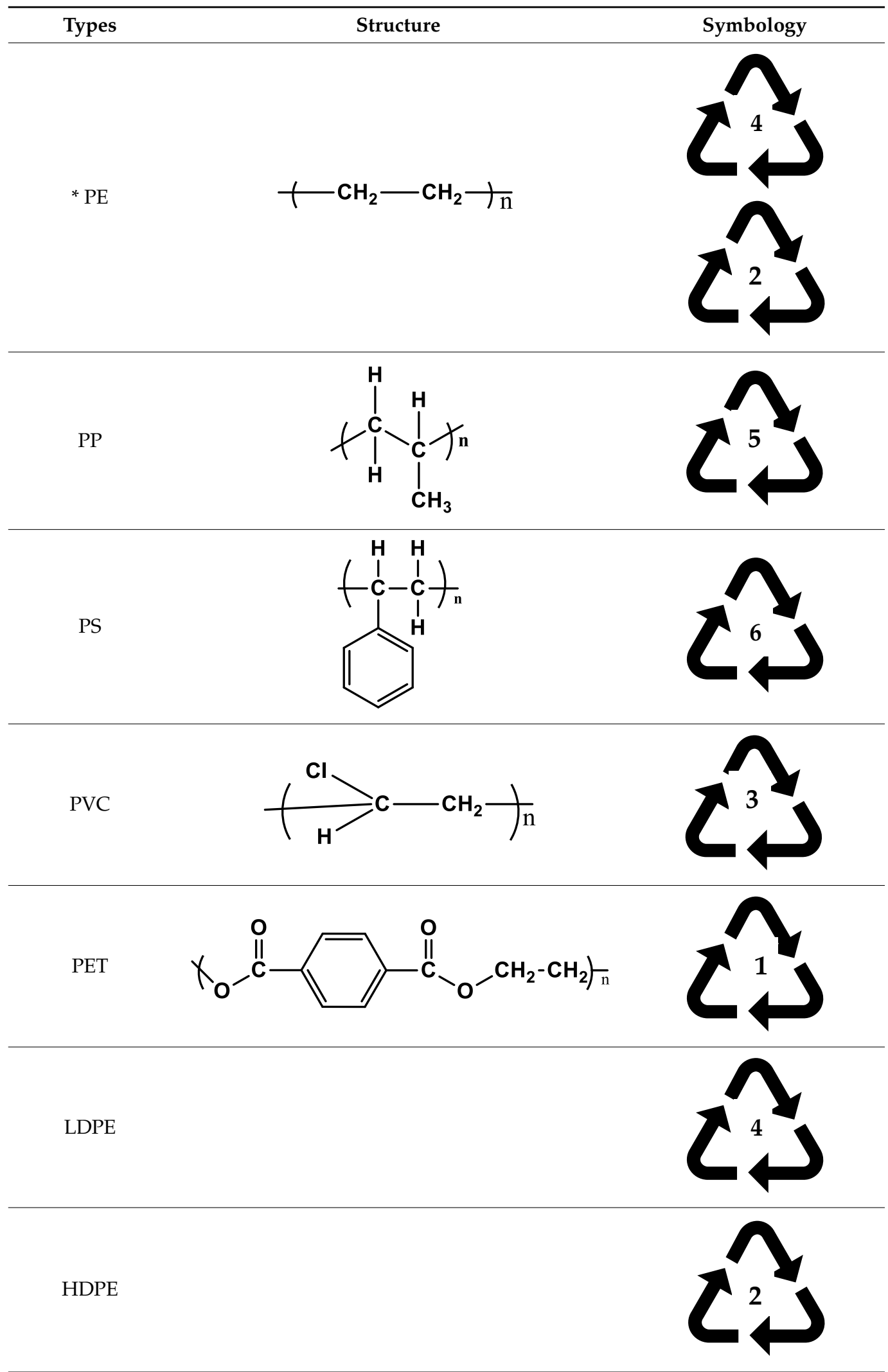


Table 1. Cont.

\begin{tabular}{ccc}
\hline Types & Structure & Symbology \\
\hline Others & & \\
\hline
\end{tabular}

* Note: 2 (HDPE) and 4 (LDPE).

\subsection{Physicochemical Properties}

Plastic properties and applications are determined by the chemical, thermal, and physical properties of the constituent polymer(s), which are determined by the molecular weight, crystallinity, and degree of interaction between polymer chains.

\subsubsection{Molecular Weight}

Molecular weight is an indication of the length of the molecule, and it is crucial in the chemical and physical properties of polymers. Furthermore, it affects their processability. The higher the degree of polymerization, that is, the higher its molar mass, the more difficult it is to mold with the application of heat and pressure, since more polymer bonds need to be broken, so there is greater energy absorption. Furthermore, the viscosity is highly dependent on molecular weight, scaling with it to the power of 3.4 due to the lower fluidity of the more entangled chains [48,49].

Polymers are different from small molecules in that they do not have a single molecular weight; instead, they exhibit a molecular weight distribution (MWD) [50]. The molecular structure, molecular weight $\left(M_{w}\right)$ and dispersity index of polymers play a critical role in their properties. Dispersity index is a measure of the molecular mass distribution in a given polymer sample [51,52]. The calculated index is the weight average molecular weight $\left(M_{w}\right)$ divided by the number average molecular weight $\left(M_{n}\right)$, and it indicates the distribution of individual molecular weight in a batch of polymers [51,52]. The dispersity index always has a value greater than 1 , but as the polymer chains approach the uniform chain length, the index approaches unity (1) [51]. The polymer dispersity index is often denoted as:

$$
\text { Dispersity index }=\frac{M_{w}}{M_{n}}
$$

Dispersity is a measure of the dispersion of a molar mass, relative molecular mass, molecular weight, or degree of polymerization distribution [52].

\subsubsection{Degree of Crystallinity}

The degree of crystallinity is directly related to density, stiffness, and the mechanical, thermal, and chemical resistance of the polymers, and is inversely related to their transparency [53,54]. Most polymers have at most $80 \%$ crystallinity, since there is no $100 \%$ crystalline polymer, as it would not be possible to mold them due to their ordered structure. Thus, the amorphous regions contribute to reducing hardness and increasing flexibility [55]. On the other hand, the crystalline regions reflect and deflect an incident light beam, compromising the regular light transmission of plastics; polymers can thus vary from translucent to opaque, depending on the degree of crystallinity [56,57].

\subsubsection{Thermal Properties}

Polymers behave like glass at low enough temperatures, i.e., below their glass transition temperature $\left(\mathrm{T}_{\mathrm{g}}\right)$. Furthermore, they behave like viscoelastic solids at intermediate temperatures, i.e., above $T_{g}$, and finally, they behave like weakly viscoelastic, high viscosity fluids at very high temperatures, e.g., above the melting temperature $\left(T_{m}\right)$ in semi-crystalline polymers. These behaviors result from the mobility of atoms in molecules 
as a function of kinetic agitation. It is for this reason that some plastics such as PE and PP have a glass transition temperature well below the usual ambient temperatures and are flexible materials, while plastics such as PS are fragile and brittle because their respective glass transition temperatures are above room temperature [58-60]. Thus, the sensitivity of plastics to temperature variation represents an advantage in production costs because these materials have a low melting point and, consequently, low energy consumption.

However, due to their high coefficient of thermal expansion, plastics tend to change their dimensions significantly, which is a problem that must be considered for certain applications [61]. Furthermore, they are poor thermal conductors in general. As a result, these materials are used in a variety of thermal insulation systems, primarily in the form of foams.

\subsubsection{Electric Properties}

Plastics are good electrical insulators, which justifies their use in electrical products. This follows from the principle that for there to be a flow of electric current, there must be electron transfer; since plastics have a low density of free electrons, they are good insulators [62]. Exceptions are the so-called intrinsically conducting polymers, which are mostly studied in the field of organic electronics, sensors, energy storage and soft robotics [63].

\subsubsection{Chemical Properties}

Plastics generally have good chemical resistance, but in all polymers, the chemical resistance is inversely proportional to temperature, since the diffusion of low molecular weight molecules is hampered by the degree of packaging of the macromolecules [64].

Despite their chemical resistance, plastics can be degraded in a variety of ways, including exposure to ultraviolet (UV) radiation. These promote the formation of crosslinks by breaking some covalent bonds in the polymer chain. One method of avoiding UV degradation is the surface addition of some material in the plastic that blocks and absorbs this radiation [65-67]. In addition to UV radiation, oxidation is also a form of degradation, in which stabilizers act on oxygen consumption before it reaches the polymer [68].

\subsection{Optimization of the Properties of Plastics}

In the plastics manufacturing process, products such as additives, dyes, and fillers are added to optimize their properties and applications. However, when a property is optimized, others can be harmed, even if they are at acceptable levels.

Common additives are antioxidants, flame retardants, lubricants, fungicides, UV stabilizers, and expanding agents, among others [69,70]. Fillers, whether in particle, e.g., carbon black, or fibrillar, e.g., glass fibers, form, typically aim to increase the mechanical strength and rigidity of plastics, as well as to allow their use under load and at higher temperatures; the most common reinforcing fillers are carbon black, carbon and glass fibers, mica, and aramids [71]. Foam polymers are made with the addition of blowing agents [72].

\section{Plastic Waste and Its Associated Health and Environmental Risks}

Plastic waste is introduced into the environment as a side product of production or as the result of improper disposal of post-consumer or post-industrial waste, contaminating the land, water, and the food chain. The first recycling initiatives for plastics occurred in the late 1960s, during the energy crisis, with the consumption of waste [73]. In this context, the reduction, reuse, and recycling ( $3 R^{\prime}$ 's) of these pollutants have been the focus of increasing research due to the benefits generated, which include cost savings, increased competitiveness, and aid in environmental preservation.

In the literature, plastic waste management steps are commonly reported, as this waste constitutes the largest fraction of solid waste worldwide. These residues come from different polymers or mixtures and are identified through the symbology contained in the desired final product (see Table 1) or based on their physical characteristics and thermal 
degradation, which are distinct [74-76]. After the first cycle of use of plastics, there is a reduction of approximately $95 \%$ in value, which results in an annual loss of value between $\$ 80$ and 120 billion worldwide [77].

Half of the plastics produced are destined for single-use applications and become waste [78]. Some strategies have been used to eliminate this waste, such as landfills. These are presented in the form of land built using various strata of soil [79]. Although landfills are the most economical option for waste management, from an ecological point of view it is unsustainable, as the waste can remain in its physical form for up to 1500 years. Alternative waste management scenarios can be categorized based on the dominant technology, namely: (i) mechanical recycling, (ii) raw material recycling, and (iii) energy recycling.

\subsection{Technology for Recycling}

\subsubsection{Mechanical Recycling}

Mechanical recycling entails the physical transformation of industrial or post-consumer polymeric waste into granules, referred to as primary and secondary recycling, respectively. To obtain the final product, waste separation, grinding, washing, drying, and reprocessing are the main stages of mechanical recycling. Thus, reprocessing can be made possible via extrusion, injection, thermoforming and compression molding, among other processes [80].

The main advantages of this technology are the high volume of waste that it allows to be recycled, and the simplified process and accessibility to small companies due to the low investment for installing a plant. In addition, mechanical recycling brings a series of benefits, namely that it is possible to minimize the volume of solid waste in landfills, to minimize the pressure on the environment for the generation of raw materials and facilitate the generation of jobs, among others [81,82]. Examples of this type of management are plastic wood, developed by two Japanese and Belgian technologies [83], and the recycling of PP packaging to obtain garbage bags [82].

\subsubsection{Raw Material Recycling}

Raw material recycling consists of the use of chemical or thermal processes as a step for the recovery of resins from polymeric waste. For this reason, it is also known as chemical or tertiary recycling. The applied process is dependent on the type of plastic, composition, and molecular mass of the desired products [84]. This technique is not commonly used in some countries, such as Brazil, due to the high cost and low purity of the resins. On the other hand, the main advantage when compared to mechanical recycling is the possibility of recycling heterogeneous plastics with impurities. An example of this technology is the pyrolysis process, in which polyolefins are depolymerized via heating, resulting in the conversion of plastic into oil and gases, which are used as inputs in the petrochemical area $[85,86]$. Nylon 6, PET, and acrylics are other examples of polymers for which this type of waste management is feasible.

\subsubsection{Energy Recycling}

Energy recycling consists of the recovery of thermal energy generated without damage to the environment from plastic waste due to its high heat capacity, which releases large amounts of heat when heated; it is also known as incineration or quaternary recycling [86]. The calorific value of $1 \mathrm{~kg}$ of plastic waste is comparable to that of $1 \mathrm{~kg}$ of fuel oil and is higher than that of coal [87]. This technique is not commonly used due to its high cost; however, countries that adopt it, such as Sweden and Austria, manage to reduce up to 90\% of the volume of waste.

The energetic use of plastic waste is one of the effective alternatives to avoid inappropriate disposal. Converting plastics to fuels can reduce harmful emissions and pathogenic contaminants compared to incineration and landfill disposal [88]. The predicted decline of fossil fuels, particularly petrochemicals that are present in the plastic itself, has attracted the attention of the scientific community to seek and obtain possible energy resources due to the continuous increase in demand for energy [89]. Fuels made from plastic are also able 
to produce a cleaner burning fuel than traditional sources due to their low sulfur content, bearing in mind that most developing countries use diesel with a high sulfur content [90]. Several studies have reported investigations of interest to industry where plastic waste has been converted into fuels, as reported recently in several investigations [91-95].

\subsection{Factors Affecting Plastics Management}

Despite the significant advances in the various recycling technologies, some factors affect the management of plastic waste recycling, namely: the existence of tax incentives, availability of technology and companies, water content, the chemical nature of materials, and the market demand for recycled plastic.

The chemical nature is important in the management of plastics, as the properties of a product can be profoundly affected if it is contaminated with another resin $[87,96]$. One of the most relevant cases is the recycling of PVC and PET: when PET is contaminated with $\mathrm{PVC}$, it will degrade during processing due to the high temperature required in this process. On the other hand, when PVC is contaminated with PET, it must be eliminated from the process, as it does not melt at the PVC processing temperature $[87,97]$.

Another very important aspect in waste management refers to the lack of tax incentives for recycling companies; consequently, the price of the recycled product exceeds that of the virgin product due to taxation. For example, in Brazil, recycled paper is more expensive than white paper.

\subsection{Recycling Issues and the Impact on the Environment}

Interest in recycling processes has been growing, but it has some limitations related to the technologies used and the type of plastic, which have significant environmental impacts. The main disadvantages associated with waste management are described below: (i) the generation of secondary solid waste since the recycling process is not efficient for the full recovery of waste [76]; (ii) the presence of inappropriate facilities for recycling different types of plastics, which are also associated with potential spaces for some types of disease [98]; (iii) high cost; (iv) environmental impacts, such as leaching of additives into the soil, water, and air; (v) taxation on recycled products, which become more expensive; (vi) the low demand for recycled materials, especially in developing countries; (vii) the fact that most plastic materials are not biodegradable; and (viii) the need for a rigorous decontamination process at a level satisfactory to health, among others. A typical case is the PET recycling process, in which the recycled product cannot be used for the production of beverage packaging, as the temperatures involved are not high enough to guarantee sterilization of the product. Furthermore, after three cycles of use, it becomes brittle and hard.

Plastic waste can cause serious impacts related to the extremes of its production chain (the depletion of raw materials and the accumulation of waste), the health of human beings, and the environment [99]. The externalities of plastic waste are concentrated in two areas, as they are easily transported through wind or water. Thus, in natural systems, they accumulate especially in the oceans, causing environmental and economic impacts, such as the death of countless fish. It is estimated that there will be more plastic by weight than fish in the ocean by 2050 [100]. Open burning of these residues releases toxic gases that aggravate the greenhouse effect and, when inhaled, cause respiratory disorders. In the field of medicine, the aggravating factors come from additives that are used in the manufacturing process [101]. Plastic waste has been extensively investigated to obtain new value-added products, such as composites applied in various industrial sectors, and for the development of technologies applied in environmental decontamination, such as supports for nanostructured catalysts. These nanostructured materials are of high importance in several catalytic applications, but their use in suspension can cause reaction problems and risks to the environment [19-21]. 


\section{Relationship between Nanotechnology and Sustainable Development}

Advances in science and technology can offer potential solutions for development in different industrial sectors, contributing to innovation, as well as adding value to their current production systems [102]. Nanoscale science and technology spans a broad and exciting scientific frontier that will have a significant impact on nearly every aspect of the global industrial economy and hence on people's lives [103-105]. Nanotechnology is characterized by very small materials called nanomaterials. Jeevanandam et al. (2018) [106] and Danish et al. (2020) [107] described nanomaterials as materials with a length of $1-1000 \mathrm{~nm}$ in at least 1 dimension; however, nanomaterials are usually defined as having diameters in the range of 1 to $100 \mathrm{~nm}[101,102]$. It is important to mention that there is no single definition of a nanomaterial that is internationally accepted, and the definition changes for each organization [106,107]. The invention of several spectroscopic techniques accelerated research and innovations in the field of nanotechnology [108]. In general, nanomaterials are classified into distinct aspects, such as dimensionality, morphology, state, and chemical composition [108-110], as shown in Figure 1.

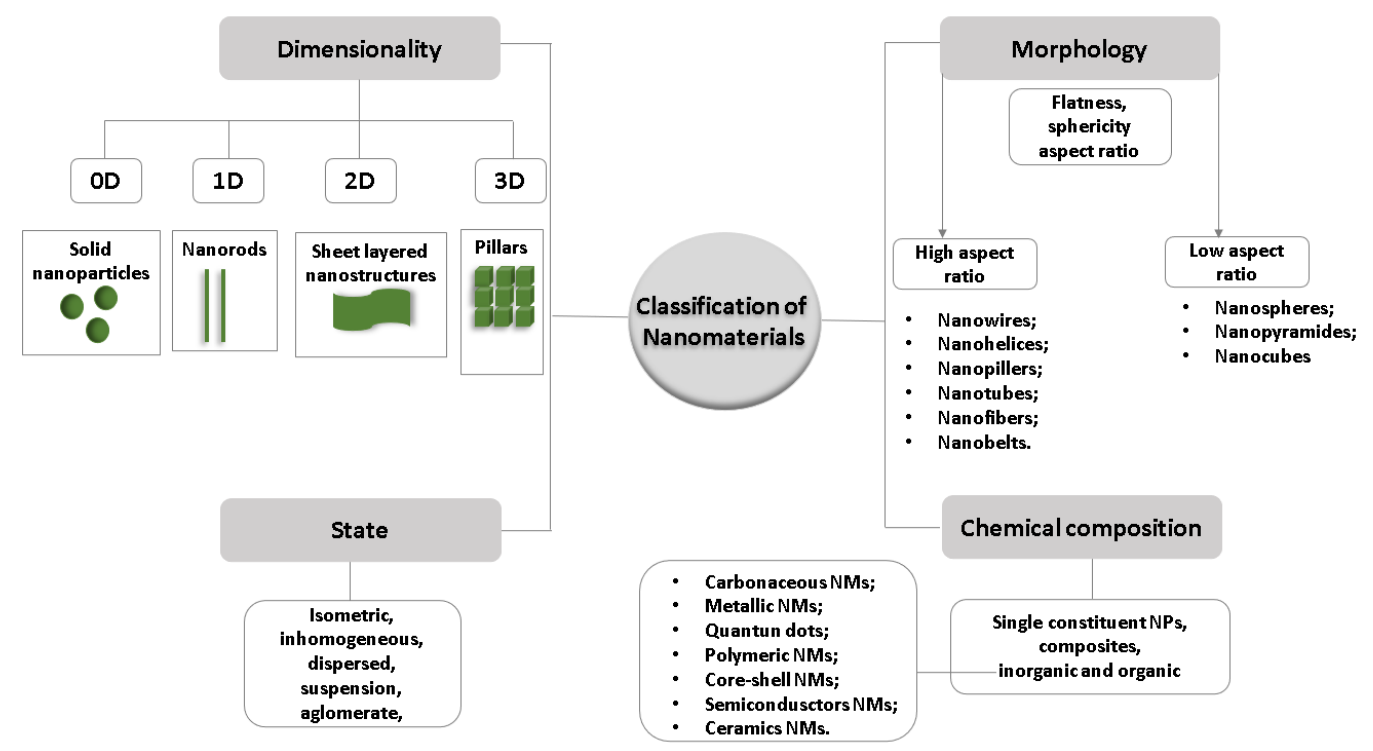

Figure 1. Schematic illustration of the classification of nanomaterials based on different criteria, Reprinted with permission from ref. [110]. Copyright 2021 Clearance Center.

In recent years, research related to nanostructured materials has been looking for ways to innovate through synthetic routes that are environmentally friendly, as there is substantial concern with nanomaterials being considered toxic in nature [111]. Studies show that these nanomaterials can be synthesized through biosynthesis, that is, from renewable sources (plant biomass), being considered "green routes" for nanotechnology [112,113]. The many uncertainties regarding the potential environmental, health and diversity effects of engineered nanomaterials pose major challenges for the responsible manufacturing and use of these substances [114-117]. In most synthesis methods presented in the literature, chemical products that are known to pose risks to human health or the environment are often used [118]. Although synthetic methods can become "greener" when moving from laboratory-scale manufacturing to industrial production, it must be ensured that the environmental benefits of using engineered nanomaterials are not overshadowed by the risks of negative effects [119].

Nanomaterials offer opportunities to develop functional materials with surface, electronic, plasmonic, optical, catalytic and magnetic properties that differ significantly when compared to macroparticles $[120,121]$, thus leading to many new applications that can be used to address numerous technical and social issues in our daily lives, such as solar cells [122-124], nanomaterials applied in medicine [125-127], gas sensors [128-130], energy 
storage and engineering [131-135] and a great highlight in the field of catalysis [136], mainly for water and effluent treatment [137-142].

In recent years, the scientific community has been striving to develop new ecological and efficient nanostructured catalytic systems $[143,144]$. Heterogeneous catalysts have been investigated and widely applied in various sectors due to their high heat stability, simplicity of recovery and separation of reaction mixtures and recyclability [145-147]. The use of these catalysts in suspension causes difficulty in recovery and loss of these materials, which often means that nanostructured waste can be dumped into the environment inappropriately [148]. One of the biggest challenges is to understand the behavior of nanoparticles in the environmental system, as it is known that the interaction between nanomaterials, the environment and the human body is complex and depends on the size and type of particle [149]. The literature has reported studies that specifically deal with the toxicity of nanoparticles, and this concern has been growing in recent years [150-152]. Therefore, immobilizing these nanostructured catalysts on supports has been the object of investigation, mainly due to the observed advantages, such as increased surface area and waste recovery for the production of catalytic supports $[153,154]$. Sustainable growth depends entirely on innovative strategies for developing new multifunctional materials [155].

The special properties of nanostructured materials have given rise to many scientific investigations and research activities aimed at the synthesis, characterization and applications of nanoparticles [106,156,157]. Regarding composition, as shown in Figure 1, nanoparticles are classified into various materials, in particular metallic nanoparticles (MNPs) and nanostructured metallic oxides (semiconductors) [158]. The first category of nanoparticles is comprised of the pure form of metal-based nanoparticles (e.g., nanoparticles of silver, copper, gold, titanium, platinum, zinc, magnesium, iron). Another category is metal oxide nanoparticles, also called nanostructured semiconductors (i.e., titanium dioxide, silver oxide, zinc oxide, among others) [158-161]. These nanomaterials are widely investigated in catalytic systems with an emphasis on developing environmentally correct processes that can promote environmental recovery in environments contaminated with waste or effluents, and even in the search for sustainable development, producing value-added molecules from renewable sources [162-165].

\subsection{Metallic Nanoparticles and Nanostructured Metal Oxides}

Nanomaterials differ from micro-sized and bulk materials not only in the scale of their characteristic dimensions, but also in the fact that they may possess new physical properties and offer new possibilities for various technical applications [166,167]; this is due to their high surface to volume ratio, which results in an exponential increase in reactivity at the molecular level [168], as well as quantum confinement effects [169]. These nanoparticles are manufactured by adding reducing or oxidizing agents and precipitants during their synthesis [167].

Metallic nanoparticles such as gold MNPs [170], iron [171], and silver [172] have been synthesized, characterized and investigated in several applications, and it has been demonstrated that these materials have very interesting surface, optical and electronic properties. Many types of nanostructured metal oxides, as $\mathrm{TiO}_{2}$ [173], $\mathrm{Fe}_{2} \mathrm{O}_{3}$ [174], $\mathrm{Al}_{2} \mathrm{O}_{3}$ [175], $\mathrm{ZnO}$ [176], $\mathrm{SiO}_{2}$ [177], $\mathrm{MnO}_{2}$ [178], and binary metal oxides [179] were investigated for different applications, demonstrating high potential due to the unique properties offered by nanomaterials. The main characteristics of MNPs are their large surface area, large surface energies, transition between molecular and metallic states providing specific electronic structures (local density of states-LDOS), plasmon excitation, quantum confinement, increased number of kinks, a large number of low-coordination sites such as corners and edges, a large number of "dangling bonds" and, consequently, specific and chemical properties and the ability to store excess electrons [180]. These characteristics make it possible to generate multifunctional materials.

Due to the change in their surface properties, metal oxide nanoparticles have important characteristics, such as their biocompatibility in providing a highly active surface 
area, and consequently, they have a wide range of applications, including as catalysts, chemical sensors, and semiconductors [181]. The electronic structure of nanostructured metallic oxides can reveal their semiconductor, metallic or insulating character [182]. The specific size of nanostructured materials, such as nanoparticles, can change their magnetic, conductive, chemical and electronic properties $[181,183,184]$. Particularly, due to the unique physical and chemical properties of metal oxide nanoparticles, a wide range of applications has been investigated in materials chemistry, medicine, agriculture, information technology, the biomedical field, optics, electronics, catalysis, environmental fields, energy applications [185-189] and in the treatment of water and effluents, among others [190-193]. Increased surface area in nanostructured metal oxides leads to increased reactivity [194]. The synthesis and investigation of these metal oxide nanoparticles are beneficial not only for the understanding of fundamental phenomena in low-dimensional systems, but also for the development of multifunctional materials with high performance in various sectors, mainly promoting systems for environmental decontamination [195].

\subsection{Problems of Use in Suspension}

Homogeneous catalysis is very efficient and selective but has some limitations in practice, such as limited thermal stability and the difficult separation of the catalyst, as it is in the same physical state as the substrate. Unlike homogeneous catalysis, heterogeneous catalysis benefits from the possible use of high temperatures and easy recovery of the catalysts, but it also has some disadvantages, such as low selectivity. However, investigations into the use of MNPs in catalysis is essential, as they mimic the activation of the metal surface and catalysis at the nanoscopic scale and, therefore, modulate nanostructured catalysts, bringing efficiency and adjusting the selectivity for reactions specific [196].

Although metallic nanoparticles have unique advantages, there are still essential disadvantages for their use in suspension in catalytic processes that should be emphasized and investigated [197]. Nanoparticles tend to aggregate due to Van der Waals interactions, thus causing a decrease in their efficiency [197,198]. Another disadvantage is the difficult separation of nanoparticles for reuse, which is still considered a major challenge. Additionally, the impact of these nanomaterials on ecosystems and human health is a significant issue that limits the use of nanotechnology in some situations [196,197]. To overcome these drawbacks, catalytically active components, such as metallic nanoparticles or nanostructured metallic oxides (usually in a low concentration), are immobilized in a dispersed state on a support $[199,200]$. Choosing a suitable, non-toxic, and recoverable support is very important [201]. It is noteworthy that in determining catalyst performance, the interaction between metal and support plays an essential role [201,202]. The most investigated supports in the literature to immobilize nanoparticles are zeolites [203,204], metal oxides $[205,206]$ silica spheres $[207,208]$ and alumina $[209,210]$; nanomaterials have also been largely immobilized in polymeric materials, adding value to waste that is normally dumped into the environment, causing problems [199,211,212]. Therefore, encouraging the choice of support based on polymeric materials is a topic of great importance. However, generally, the polymeric support does not show any catalytic activity on its own, but it can cause important changes in the surface and structural properties of the final material. Thus, it is increasingly necessary that the properties of these materials as supports be investigated in heterogeneous catalysis.

\section{Turning Plastic Waste into Valuable Products}

\subsection{Accumulation of Plastic Waste in the Environment}

Research and development related to synthetic polymers has largely focused on their useful properties and applications [213]. These inherent advantages of plastic materials are converted into their most serious disadvantages when they become waste; for example, they do not oxidize like metals or degrade chemically like cellulose- and protein-based materials. Another factor is related to contamination in water bodies; the density of these residues can be close to that of water and for this reason, plastic waste floats near the surface 
of the water where fish and the rest of aquatic life are [214]. As a result, post-consumer plastic waste disposal has led to plastic pollution in landfills and waterbodies and now represents a global environmental challenge [213]. The excessive use of disposable products has led to an exponential increase in the amount of plastic waste from land and sea activities, resulting in considerable economic, environmental and social problems $[210,211]$.

The non-biodegradability and poor management of plastic waste can cause several environmental risks regarding the safety and clogging of sewage in urban cities and other production areas [19]. In addition to the contamination caused by plastic waste in the environment, climate-induced degradation is also a problem. Plastic waste can heat up to $40{ }^{\circ} \mathrm{C}$ on beaches, which further accelerates wear and degradation by sunlight, potentially causing the formation, for example, of microplastics. Literature often classifies plastic waste present in water bodies by size. The most common classification is microplastics, mesoplastics and macroplastics, but their size ranges are not uniform, as explained by Ronkay et al. (2021) [215] and by Shah et al. (2015) [216]. The ingestion of plastics by aquatic organisms is an emerging environmental crisis due to the spread of these contaminants in water bodies [217-219]. These plastic residues, when ingested, can cause physical obstruction of their digestive systems [220]. Therefore, the overall potential impact of microplastic pollution on aquatic systems can have serious consequences [219,221].

Pollution from plastic waste is an emerging global environmental problem [222]. These wastes have drawn a lot of attention due to their increasing numbers in the global economy, their low material recovery rates and the environmental impact associated with current disposal methods. Pillai (2021) [223], in his recent study, presented important information, such as a report by the United Nations Environment Program (UNEP) showing that around 400 million tons of single-use plastic waste is produced annually ( $47 \%$ of total waste plastic) and estimating that only around $9 \%$ of this plastic waste is being recycled worldwide. The numbers are worrying, and the efforts currently being made by several economies are very timid compared to the desired goals [223]. Due to inadequate waste management practices, plastic waste disposed of arbitrarily generates serious environmental pollution [224,225]. Strengthening waste management practices (segregated waste collection and waste processing through material recovery facilities in cities) can help put plastic waste back into the circular economy cycle [211]. While each country is responsible for developing unique waste management initiatives, cleaning up our planet is, in fact, a collaborative effort. It is vital that nations inspire each other and adopt contemporary, innovative, and sustainable practices that help solve the growing problem of plastic waste around us [223].

Recycling refers to the waste management method that collects waste and transforms it into raw materials that can be reused for the manufacture of other valuable products that are suitable for use in the production of new products applied in different sectors [226]. It is also known as "renew or reuse" to prevent harmful effects on society and the protection of the environment [226]. The conversion and/or recycling of plastic waste encompasses any method where plastic waste is transformed rather than discarded. [227,228]. Plastics have inherent properties to be reused, and this is attributed to the quality of the recovered waste fraction. Common plastic wastes primarily include polyethylene (PE), polystyrene (PS), polyvinyl chloride (PVC), polyethylene terephthalate (PET), high-density PE (HDPE) and polypropylene (PP), and it is estimated that over $60 \%$ of plastic waste urban solids are composed of polyolefins, mainly low-density PE (LDPE), linear LDPE, HDPE, and PP [229]. Plastic waste from these polymers has complex mixtures of additives to configure specific properties in the final material, including, for example, thermal stabilizers, lubricating pigments, heat and light stabilizers, antioxidants, flame retardants and plasticizers $[230,231]$. The literature has reported that some of these additives have characteristics of endocrine-disrupting chemicals (EDCs), such as bisphenol A (BPA) and diethylhexyl phthalate (DEHP) [231], and these and other additives were classified as persistent contaminants [231]. As the content of additives in different waste products with different purposes can vary greatly, the chemical composition of recycled plastic is often unknown [232], which causes concern about the inappropriate disposal of this plastic waste into the environment, 
and the high degree of contamination, mainly in water bodies, with contaminants that are normally difficult to remove in conventional treatments.

Despite the significant development of various technologies to deal with plastic waste and its conversion into molecules of industrial interest or the manufacture of new valueadded materials in different sectors, this conversion remains a challenge [233]. The reuse of plastic as an aggregate in the manufacture of new materials can contribute to the elimination of this waste and help protect the environment and achieve sustainable development $[234,235]$. These new materials can be obtained through different processes, and each process depends on the characteristics and destination of plastic waste. Recently, a study presented by Zhao et al. (2022) [228] showed different recycling routes for plastic waste. Different processes have already been investigated according to each destination, as they need to be applied to specific plastic waste due to their advantages and disadvantages, as shown in Figure 2. To understand the processes used to transform plastic waste into valuable products to pursue sustainable development, it is essential to understand the different plastics, the waste management chain, and the distribution components. This is essential to understand the nature of the problem and perform the best measures to reduce plastic waste improperly dumped into the environment [231].

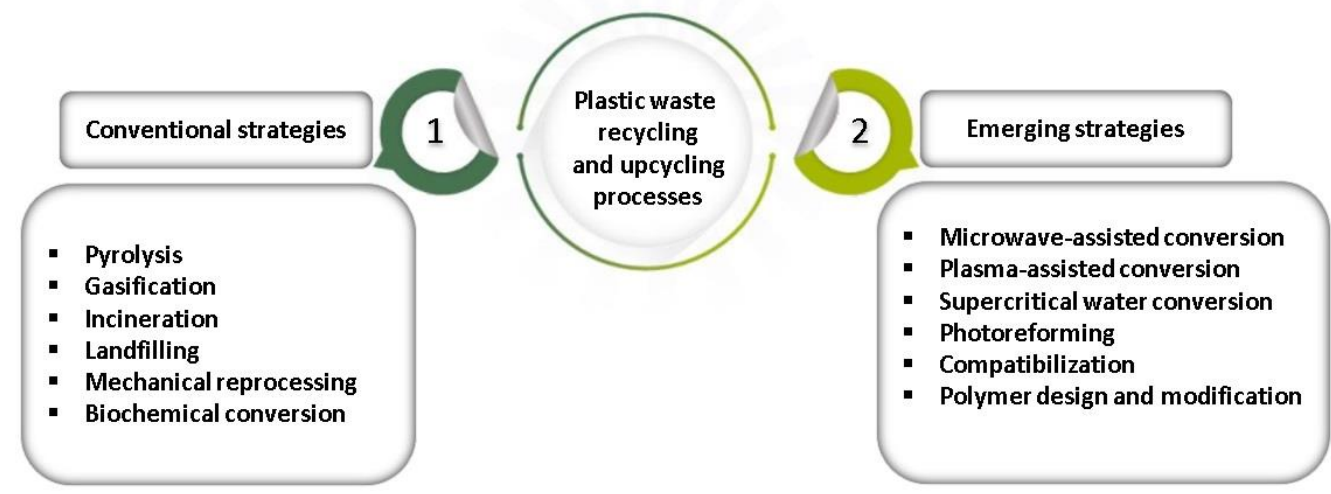

Figure 2. Plastic waste conversion strategies. A comparison of conventional and innovative strategies for converting plastic waste. Reprinted with permission from ref. [228]. Copyright 2022 Elsevier.

Importantly, the use of evolving innovative technologies and practices can increase the efficiency of supply chains as well as organizations, while reducing environmental degradation through its economic flourishing. Resource recovery leads to the evolution of new value-added materials from plastic waste [226,236]. While recycling has different benefits for the community, it also has some disadvantages that should be emphasized and discussed. During the recycling process, chemicals may be released into the environment. Among these chemicals, some are volatile gases from plastic waste compositions and organic chains of monomers that can be harmful to plant structure and affect wildlife when inhaled by different animals that live near the recycling zone. That said, this emphasizes the importance of management and care [226,236].

The use of plastic waste as a starting source to produce value-added products and/or materials has been proposed as the necessary impetus to increase the attractiveness of plastic recycling [237]. When plastic waste is transformed into these new products, there are many essential factors that need to be considered, as the addition of plastic waste can affect the performance of the composite materials produced [238]. In particular, the scientific community has focused on suggesting alternatives for the inclusion of plastic waste in various sectors, such as construction materials [238-242], ultrafiltration membranes for water treatment [243-245], 3D printing [246-249], components in asphalt [250-253], wallpaper [254], and the agricultural sector [255], among others, as shown in Figure 3. Plastic waste can also be recycled and used to make composite materials. A composite is a material 
of superior quality resulting from the combination of two or more other components, whose properties are not separately satisfactory for a specific purpose [256].

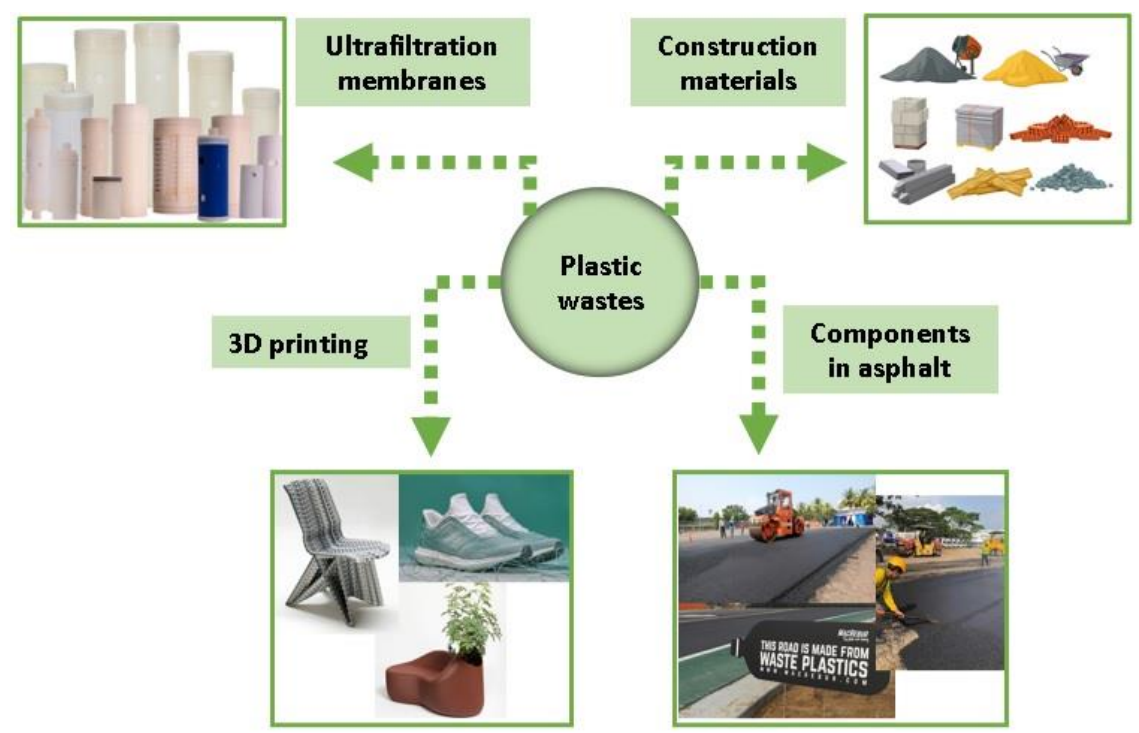

Figure 3. Possibilities of applying plastic waste towards products of added value and industrial interest.

In this context, the incorporation of plastic waste in matrices of certain materials can improve mechanical properties in addition to improving other properties. In this sense, several successful attempts to obtain composites from plastic waste are already reported in the literature $[257,258]$, some of which will be discussed in the following topic.

Circular economy (CE) has a significant sustainability potential [259]. CE, whether considered as a concept or an industrial system, has gained interest among practitioners, politicians, and scholars alike [260]. The circular economy of plastics is a possibility for the executed linear system, where plastic is obtained, applied, and discarded. CE's objective is to maximize the amount of plastic that is reused or recycled back into the system [261], and it was created from the concept that we can create sustainable human systems, mimicking the sustainable processes of nature. The principles of circular economy are based on abandoning the idea of products and materials ever becoming waste and instead, the circular economy concept envisions "an economic system that replaces the 'endof-life' concept with reducing, alternatively reusing, recycling and recovering materials in production/distribution and consumption processes. It operates at the micro level, meso level and macro level, with the aim to accomplish sustainable development, thus simultaneously creating environmental quality, economic prosperity and social equity, to the benefit of current and future generations. It is enabled by novel business models and responsible consumers" [262-264].

\subsection{Polymeric Composites for Waste Recovery}

The recycling of plastic waste represents not only an opportunity to update waste management practices, but also a path to sustainable economic development through revaluation [265]. Composite materials can be defined as a combination of at least two different materials that are combined to obtain a third material with mechanical properties superior to the properties of its individual components [266]. The recovery of waste and its application in obtaining composites for different applications has been increasingly investigated, with significant results and applications in different areas.

PET is one of the most-recycled polymers in the world and has about $22 \%$ recycling fraction in its current supply $[267,268]$. Its properties, uses and industrial innovations that increase the demand of its consumers result in the generation of tons of waste discarded into the environment [269]. Taking into account two serious problems for the environment, 
namely the high amount of air pollutants from anthropogenic activities and plastic waste discarded in the environment, where almost $40 \%$ is polyethylene terephthalate (PET), recently, Kakoria et al. (2021) [270] sought to bridge the gap between plastic waste and personal protection using discarded PET bottles as a reference material, and developed PET-based nanostructured composites for the fabrication of membranes for air filters and/or face masks. The authors showed that ultra-fine PET nanofibers were successfully manufactured from plastic bottles for application as face masks or air filters [270]. The use of PET waste in adequate proportions to obtain composites can improve some properties [271]. Recently, Aydogmus et al. [272], produced a biocomposite reinforced with polyethylene terephthalate waste, and it was observed that the behavior of the biocomposite at high temperatures improved with increasing PET waste content. The use of PET waste presents an environmentally correct and economical solution [272].

Concern about plastics is also heightened when it comes to polypropylene, which is one of the least-recycled plastics, with a recycling rate of just $0.6 \%$, according to a report by the Environment Protection Authority (EPA-USA) [273], representing a serious environmental concern. Recently, Pasternak et al. (2021) [274] used polypropylene waste to obtain composites and manufacture ceramic membranes applied in microbial fuel cells (MFCs). It is important to mention that this study is a pioneer of using polymeric residues for this purpose. According to Pasternak et al., polypropylene waste has increased the useful life of ceramic MFCs, mainly suggesting strong antifouling effects, using a sustainable approach where, at the same time, problematic plastic waste is being recycled. Furthermore, according to the authors, what promotes these properties is the interaction of the interface between the ceramic and polymer layers where they can play an important role in establishing the proper morphology of the polymer coating to facilitate the transfer of protons and inhibit biofouling [274]. Polypropylene waste has also been used in other applications, for example, in the search to produce composites to obtain panels that can be used as commercial support materials, as presented by Sezgin et al. (2021) [275]. In this study, the authors recycled plastic bottle lids of polypropylene and polyethylene, which are generally used in food and cleaning containers, to become matrix material to produce composites and panels. These panels were investigated in terms of air permeability and thermal and acoustic insulation behavior. The results indicate that the developed panels are applicable as commercial support materials and offer improved thermal and acoustic insulation properties [275]. In the civil construction sector, polypropylene waste and polyethylene waste were investigated in the production of composites for obtaining polyester-based polymeric mortars by Martínez-López et al. (2021) [276], and the results indicated that there was a significant improvement of $82 \%$ in flexural deformation in the presence of polypropylene residue. They also observed a $30 \%$ improvement in compressive deformation with polyethylene waste and a $27 \%$ improvement in compressive strength with polypropylene waste [276].

Lin et al. (2020) [277] investigated the recovery of acrylonitrile butadiene styrene (ABS) residues to obtain laminar mortar-polymer composites for applications in the civil construction sector, specifically in 3D printing. Polymer reinforcement allowed the mortarcontaining residual materials to maintain high ductility [277]. The study by Li et al., in addition to other investigations, provides alternatives for reusing ABS waste to manufacture high value-added products, which represents a promising way of recycling waste and mitigating environmental problems with inadequate disposal $[277,278]$. Zulkernain et al. (2021) [279] also investigated the use of plastic waste applied in the civil construction sector. The authors investigated the use of plastic as an aggregate in terms of physical, mechanical and durability properties of construction materials, as well as environmental and cost analysis. According to the study, it was observed that the mechanical and durability properties of the materials produced were changed after the addition of plastic as an aggregate, but the materials met the requirements of construction materials.

Polyvinyl chloride (PVC) is one of the most-used thermoplastic materials in relation to the worldwide consumption of polymers [280]. As a result of the increased consumption of 
PVC products in recent years, the amount of used PVC items entering the waste stream has increased gradually [281]. Processes such as incineration and the disposal of PVC waste in landfills typically release hazardous compounds such as polychlorinated dibenzo-pdioxins (PCDD) and dibenzofurans (PCDF) [282]. Therefore, seeking alternative processes for the environmentally correct disposal of this waste is necessary. PVC waste has been extensively investigated in composite fabrication application for filtration and ultrafiltration membranes [283-285]. PVC waste was investigated by Aji et al. (2020) [286] to obtain ultrafiltration membranes. PVC waste was blended with cellulose acetate to overcome the hydrophobic nature of PVC in membrane manufacturing. The results showed that the hydrophilicity of the prepared membranes was increased to about $25 \%$. Thermal stability was improved in membranes blended with PVC. These results provided the insight that PVC waste can be used to manufacture ultrafiltration membranes [286].

Polystyrene (PS), as one of the top five most-consumed plastics, has been widely applied in the electronics, construction, transportation, packaging and other daily supply industries. Due to its wide ranges of production and use, a large amount of polystyrene waste is dumped into the environment every year, especially into the marine environment, severely threatening the global biosphere [287]. However, research has shown satisfactory results in the disposal of polystyrene waste for various applications, for example in the use of these materials as an adsorbent in environmental remediation. Mehmandost et al. (2019) [235] manufactured a composite from polystyrene and cotton waste, and the material obtained allowed the removal of oil and polycyclic aromatic hydrocarbons (PAHs) from the water. The polystyrene residues investigated by the authors came from yogurt packaging. The composite showed significant potential for the removal of fluorene, anthracene, fluoranthene and pyrene. An important observation in this study is that despite the conversion of polystyrene waste into a useful destination material for the quality of environmental systems, chloroform is used during its synthesis, and the risk associated with any leakage must be considered; this observation is also reported by the authors [235]. Recently, Gao et al. (2022) [288] showed that polystyrene residue can be reused to obtain composites with flame retardant properties and has potential for obtaining electromagnetic interference (EMI) protection materials. The authors noted that the segregated structure can influence the formation of a compact conductive network to improve electromagnetic shielding properties [288]. Polystyrene residue was also investigated in composites for applications in the civil construction sector [289-293], as well as in other sectors [294-297], and demonstrated viability and improvement of the resulting material for the recovery of residues that are inserted into the environment, in most cases, inappropriately.

The real possibility of manufacturing the described materials from plastic waste is related to the peculiarity of plastics as materials to produce various basic products, especially the fact that they preserve some properties even after being discarded and classified as waste [298]. Through the aforementioned investigations, many advantages of these new composites generated from polymeric waste can be observed, such as obtaining valueadded products, which can be applied in various sectors [289]. It is important to mention that, here, we focus on the approach of composites filled with metallic nanoparticles and nanostructured oxides; however, composites from plastic waste mixed with other filling materials are also reported, such as layered silicates [4], graphene [238], and POSS [256]. It is worth mentioning that, in addition to the applications mentioned above for the destination of polymeric waste, these wastes have also been investigated as catalytic supports, ensuring quality in environmental systems. This investigative line has been the focus of many researchers in recent years, and some of the studies will be addressed in the next topic.

\subsection{Catalysis Opportunities: Supports for Heterogeneous Catalysts}

Homogeneous and heterogeneous catalysis plays an important role in industrially important organic transformations that produce some significant chemicals used in the petrochemical, pharmaceutical and fine chemical industries [299]. While homogeneous 
catalysts offer many advantages like high reaction rates, easy accessibility of active sites, and minimal diffusion barriers, separation from the reaction mixture is a tedious task, and, in some cases, it is a challenging process [300]. Heterogeneous catalysis is preferably used in industrial applications because of its easy separation, which usually results in lower operating costs [301]. Heterogeneous catalysis and solid catalysts play an essential role in the field of chemical engineering, renewable energy and batteries [302], but one of the challenges is to obtain catalytic systems that can be recovered and reused in subsequent reaction cycles, thus minimizing costs, and also obtaining materials with a high surface area. Since catalysis takes place on the surface of nanocatalyst particles, catalysts are prepared in order to expose a large area of metal, and supports for solid catalysts contribute strongly to that end. Plastic waste is considered a technically viable material for use as catalytic supports since it is used in large quantities and at a low cost. Supported catalysts are in high demand because their mesoporous supports expose metal active centers, favoring catalytic action to destroy and/or produce desirable products [216,303,304]. Nanocatalystsupport interactions in these materials can have a substantial influence on catalysis, making nanocatalyst-support interaction modulation one of the few tools able to enhance catalytic performance [305]. Further on, some investigations on polymeric supports for catalysts that stood out in the last five years will be discussed.

Recently, Valadez-Renteria et al. (2021) [19] used polymer waste from recycled bags (RBag) or recycled polystyrene (RPS) from food packaging to manufacture flexible and efficient photocatalytic composites applied in the photodegradation of the pesticide 4chlorophenol. The waste came from recycled polypropylene/polyethylene high-density bags and polystyrene food packaging. The active photocatalyst supported on recycled polymers was a $\mathrm{CuS} / \mathrm{TiO}_{2}$ (CuST) nanocomposite. According to the authors, CuST was selected because it is non-toxic and has high chemical stability and a high surface area. The composites RPS-CuST and RBag-CuST produced maximum degradation percentages of 89 and $100 \%$, respectively, thus demonstrating the feasibility of converting polymeric residues into products with a valuable destination for removing contaminants from water through heterogeneous photocatalysis [19]. The conversion of polystyrene waste into value-added composites was also investigated by our research group, as presented by Assis, et al. (2018) [20], where it was shown that combining two issues of emerging concern (exploring the reuse of polystyrene and water contamination by toxic dyes) is an important line of investigation in the development of multifunctional materials. The investigation resulted in the fabrication of polystyrene-based nanofoams to support nanostructured $\mathrm{SnO}_{2}$, and then evaluated these photocatalytic systems for applications in the photodegradation of rhodamine $\mathrm{B}(\mathrm{RhB})$ with the purpose of environmental remediation and water decontamination. The authors demonstrated that the surface area of the composite was greater than that of individual $\mathrm{SnO}_{2}$; this increase in surface area influenced the increase in the photodegradation rate, and all the composite materials investigated had rates above $96 \%$ of photocatalytic efficiency in 70 min reactions. In addition to dye discoloration, the authors estimated the formation of less toxic by-products. Therefore, the combination of polystyrene $/ \mathrm{SnO}_{2}$ caused a synergy for the achieved result [20].

Moura et al. (2021) [21] used polystyrene residues from post-consumer yogurt packaging to manufacture films for the immobilization of $\mathrm{TiO}_{2}$ impregnated with copper and iron for application in photocatalytic systems in the degradation of the drugs ketoprofen, tenoxicam and meloxicam. The results showed that the photodegradation kinetic rates reached values above $92 \%$ after $180 \mathrm{~min}$ of reaction. The authors also evaluated the toxicity before and after the treatment, and no toxicity was observed for the watercress and lettuce seeds; however, the results showed a small sensitivity for thyme seeds to the compounds formed during the treatment. Furthermore, the efficiency of reuse of the photocatalyst was also evaluated, and after the fifth treatment cycle, the supported photocatalyst still showed degradation greater than $82 \%$. These results indicate that this photocatalytic system is suitable for the treatment of effluents containing pharmaceutical compounds [21]. 
Water contamination with nitrates is prevalent worldwide, and it was with this concern that Sandhu et al. (2020) [306] investigated efficient photocatalytic systems for denitrification. For this, the synthesis of $\mathrm{TiO}_{2}$ nanoparticles immobilized on polystyrene $\left(\mathrm{PS}-\mathrm{TiO}_{2}\right)$ was investigated. According to the authors, the fluctuating nature of the catalysts allowed their easy recovery, with $98 \%$ catalyst recovery rates after 5 cycles of denitrification experiments [306]. The idea of immobilizing the photocatalyst on a floating support can support minimizing photocatalyst recovery and powder filtration problems, offering greater adaptability in using the supported photocatalyst for scale-up structures [306,307]. In addition to the concern with nitrate-contaminated water, as discussed above, phosphorus has been causing emerging concern in water bodies. Phosphorus is an essential nutrient for all living beings; however, excess phosphorus is the limiting factor for eutrophication [308,309]. One of the main sources of phosphorus pollution is the discharge of wastewater [308,309]. Therefore, recently, Zhao et al. (2021) [308] manufactured a polystyrene-based composite (host) to support nanostructured $\mathrm{ZrO}$, and the resulting material was applied to remove phosphate by adsorption. The results showed that the polymeric host facilitated the formation and dispersion of nanoparticles with smaller sizes compared to another investigated composite (with macroporous anion exchanger), exposing a greater amount of highly accessible surface hydroxyl groups to phosphate. In fact, the embedded nanoparticles increased the porosity and affinity of phosphate with the gel polymer. This relatively cheaper host (polystyrene) can be an alternative to the macroporous anion exchanger, providing a new strategy for the immobilization of functional nanoparticles for phosphate mitigation in water [308]. Patel and Vasava (2020) [310] presented an interesting discussion between the combination of support from polystyrene for metallic nanoparticles and the observed better responses of catalytic systems [310].

In addition to investigations using polystyrene, other polymers have also been studied in the manufacture of supports for catalysts, as demonstrated by Sandoval, et al. (2017) [311], who in addition to polystyrene residues also used polyethylene terephthalate residues (PET) as supports for $\mathrm{TiO}_{2}$ and $\mathrm{ZnO}$. The materials were applied as photocatalysts for the degradation of two commonly used azo dyes: Acid Brown 83 (AB83) and Direct Blue 1 (DB1). According to the authors' observations, no statistically significant differences were found between the use of PET and PS as substrates in the degradation rate constants for both dyes; however, the adsorption of both dyes was greater in $\mathrm{TiO}_{2}$ than in $\mathrm{ZnO}$. The complete photocatalytic degradation of $\mathrm{AB} 83$ and $\mathrm{DB} 1$, being $\mathrm{TiO}_{2}$ - and $\mathrm{ZnO}$-supported on PS and PET, did not exceed 50 reaction minutes. Considering that both PET and PS are generally discarded materials after their primary use, the recovery of these materials for water treatment purposes is an attractive alternative [311].

Important results were also presented by Mossmann et al. (2019) [312], who synthesized zero-valent iron catalysts $\left(\mathrm{ZVI} / \mathrm{Fe}^{\circ}\right)$ supported on low density polyethylene (LDPE), resulting in a floating composite which was applied in the photo-Fenton process for the treatment of a synthetic effluent containing Ponceau $4 \mathrm{R}$, a dye widely used in food industries, but which has high solubility in water and significantly affects aquatic photosynthetic activity due to reduced light penetration [313]. Furthermore, according to Mossmann et al., the resulting material showed satisfactory catalytic activity, reaching total discoloration of the Ponceau $4 \mathrm{R}$ dye after 15 min of reaction. In addition, the floating catalyst exhibited other advantages, such as easy separation from the aqueous solution, good stability, and recyclability [312].

Polyvinyl chloride (PVC) is an important polymer in industry and society, and in investigations presented by Linda et al. (2016) [314], the authors evaluated the fabrication of a composite (cellulose/PVC) to immobilize nanostructured $\mathrm{ZnO}$ which was to be applied in the ultraviolet light-assisted photodegradation of Congo red and crystal violet dyes. According to reaction observations, almost $90 \%$ of the dyes were degraded after $120 \mathrm{~min}$. The results indicated that the presence of cellulose improved surface and structural properties, increased the affinity of the composite with the reaction medium, and increased the photocatalytic efficiency when compared to PVC/ZnO. Given the above, the 
$\mathrm{ZnO}$ photocatalyst supported on polymer composite can be considered promising for the photodegradation of organic dyes [314].

The notable advantage of such supports from plastic waste for catalysts lies in their conversion, reuse, their low price, and the possibility of their use in important procedures for the quality of environmental systems [315]. Catalyst reuse is as important as catalytic activity for the application of hazardous species degradation. As discussed in the examples mentioned above, using polymeric supports from waste to manufacture supports for nanostructured catalysts is an alternative that offers the possibility of developing catalysts with different benefits, such as increased surface area, and this helps in maximizing the use of the efficiency of the light, since there is the possibility of reaching a greater number of active sites, high degradation efficiency, easy post-treatment recovery and possibility for reuse over several cycles without significantly decreasing efficiency [316,317]. Porous supports are crucial to guarantee the uniform distribution of the metallic particles and to avoid the agglomeration of the catalyst particles. The surface, structural and electronic properties of catalysts supported on plastic waste can be adapted according to the requirements of the desired product and application as well. The methods of preparation of these materials directly influence these properties [315].

\section{Plastics and the Future}

Since 1964, the production of plastics has increased significantly, with a forecast that by the year 205012 billion tons of waste will have been introduced in the environment [318]. The main factors for these implications can be categorized by the continued growth of population and consumption of products. In this context, technological and governmental actions and interventions are needed to remediate these residues sustainably.

For better management in the technological sphere, recycling facilities should be improved and consumption of recycled plastics increased so that production supervision and disposal are monitored [319,320]. From the governmental side, scientific research focused on the investigation of environmental problems and medium and long-term dangers for living beings should be promoted, so that there is an increase in awareness about their management. This could include, for example, changing the habit of throwing garbage in the streets [86].

One of long-term solution from green alternatives is the production of biodegradable plastic materials that are competitive with ordinary plastic, resulting in the expansion of the social and financial character, particularly in developing countries where, due to eating habits, a higher consumption of plastics, such as packaging, can result in better biodegradability rates [321].

Plastic packaging represents the largest application of plastics, totaling $26 \%$ of the total volume. In 2015, the International Energy Agency World Energy Outlook estimated that production could quadruple to approximately 318 million tons annually by 2050, which is higher than the entire plastics industry at the time [34]. Several countries, especially European ones, are developing public policies to include the use of biopolymers in packaging; for example, France and Germany signed a Circular Plastic Alliance in which they intend that $90 \%$ of domestic packaging will be reusable by 2025 . The (EU) 2018/852 directive envisions all packaging materials on the continent to be $100 \%$ reusable, so incineration rates in 2050 are expected to be $50 \%$ (44\% recycling and 6\% of waste disposed of). Future studies will be published on trends in the amounts of plastic waste generated after legislative measures are adopted by countries [71].

Author Contributions: Conceptualization, R.J.d.O. and G.C.d.A.; methodology, G.C.d.A., R.A.d.J. and W.T.A.d.S.; formal analysis, G.C.d.A., R.A.d.J. and R.J.d.O.; writing-original draft preparation, G.C.d.A., R.A.d.J. and W.T.A.d.S.; writing — review and editing, R.J.d.O., L.F.R.F. and R.T.F. All authors have read and agreed to the published version of the manuscript.

Funding: This research was funded by FAPESQ, grant number 005/2018 and PROPESQ 2017/UEPB. The APC was funded by FULL FEE WAIVER by MDPI. 
Institutional Review Board Statement: Not applicable.

Informed Consent Statement: Not applicable.

Data Availability Statement: Not applicable.

Acknowledgments: R.J.d.O acknowledges FAPESQ and PROPESQ-UEPB for funding.

Conflicts of Interest: The authors declare no conflict of interest.

\section{References}

1. Patni, N.; Shah, P.; Agarwal, S.; Singhal, P. Alternate Strategies for Conversion of Waste Plastic to Fuel. ISRN Renew. Energy 2013, 2013, 902053. [CrossRef]

2. Al Rayaan, M.B. Recent advancements of thermochemical conversion of plastic waste to biofuel-A review. Clean. Eng. Technol. 2021, 2, 100062. [CrossRef]

3. Yeung, W.S.; Loh, W.W.; Lau, H.H.; Loh, X.J.; Lim, J.Y. Catalysts developed from waste plastics: A versatile system for biomass conversion. Mater. Today Chem. 2021, 21, 100524. [CrossRef]

4. Istrate, O.M.; Chen, B. Structure and properties of clay/recycled plastic composite. Appl. Clay Sci. 2018, 156, 144-151. [CrossRef]

5. Zhang, Z.; Han, X. Polymer antibacterial agent immobilized polyethylene films as efficient antibacterial cling film. Mater. Sci. Eng. 2019, 105, 110088. [CrossRef]

6. Far, H.; Nejadi, S. Experimental investigation on interface shear strength of composite PVC encased macro-synthetic fibre reinforced concrete wall. Structures 2021, 34, 729-737. [CrossRef]

7. Peitsch, W.K.; Hofmann, I.; Bulkescher, J.; Hergt, M.; Spring, H.; Bleyl, U.; Goerdt, S.; Franke, W.W. Drebrin, an Actin-Binding, Cell-Type Characteristic Protein: Induction and Localization in Epithelial Skin Tumors and Cultured Keratinocyte. J. Investig. Dermatol. 2005, 125, 761-774. [CrossRef]

8. Sharma, B.; Goswami, Y.; Sharma, S.; Shekhar, S. Inherent roadmap of conversion of plastic waste into energy and its life cycle assessment: A frontrunner compendium. Renew. Sustain. Energy Rev. 2021, 146, 111070. [CrossRef]

9. Dedman, J.; Christie-Oleza, J.A.; Fernández-Juárez, V.; Echeveste, P. Cell size matters: Nano- and micro-plastics preferentially drive declines of large marine phytoplankton due to coaggregation. J. Hazard. Mater. 2022, 424, 127488. [CrossRef]

10. Carpenter, E.J.; Smith, K.L. Plastics on the Sargasso Sea Surface. Science 1972, 175, 1240-1241. [CrossRef]

11. Gündoğdu, S.; Eroldoğan, O.T.; Evliyaoğlu, E.; Turchini, G.M.; Wu, X.G. Fish out, plastic in: Global pattern of plastics in commercial fishmeal. Aquacultur 2021, 534, 736316. [CrossRef]

12. Huang, J.; Veksha, A.; Chan, W.P.; Giannis, A.; Lisak, G. Chemical recycling of plastic waste for sustainable material management: A prospective review on catalysts and processes. Renew. Sustain. Energy Rev. 2022, 154, 111866. [CrossRef]

13. Gaurav, T.; Chetna, T.; Bhashkar, S.B.; Sandeep, P.; Manoj, K.; Sumit, K.; Himani, T.; Sunil, D.; Nanda, G.S. Waste plastic derived graphene sheets as nanofillers to enhance mechanical strength of concrete mixture: An inventive approach to deal with universal plastic waste. Cleaner Eng. Technol. 2021, 5, 100275.

14. Gaggino, R.; Positieri, M.J.; Irico, P.; Kreiker, J.; Arguello, R.; Sánchez, M.P.A. Ecological Roofing Tiles Made with Rubber and Plastic Waste. J. Adv. Mater. Res. 2013, 844, 458-461. [CrossRef]

15. Agyeman, S.; Obeng-Ahenkora, N.K.; Assiamah, S.; Twumasi, G. Exploiting recycled plastic waste as an alternative binder for paving blocks production. Case Stud. Const Mater. 2019, 11, e00246. [CrossRef]

16. Olofinnade, O.; Morawo, A.; Okedairo, O.; Kim, B. Solid waste management in developing countries: Reusing of steel slag aggregate in eco-friendly interlocking concrete paving blocks production. Case Stud. Const Mater. 2021, 14, e00532. [CrossRef]

17. Chanhoun, M.; Padonou, S.; Adjovi, E.C.; Olodo, E.; Doko, V. Study of the implementation of waste wood, plastics and polystyrenes for various applications in the building industry. Constr. Build. Mater. 2018, 167, 936-941. [CrossRef]

18. Rajmohan, K.; Ramya, C.; Viswanathan, M.R.; Varjani, S. Plastic pollutants: Waste management for pollution control and abatement. Curr. Opin. Environ. Sci. Health 2019, 12, 72-84. [CrossRef]

19. Valadez-Renteria, E.; Barrera-Rendon, E.; Oliva, J.; Rodriguez-Gonzalez, V. Flexible $\mathrm{CuS} / \mathrm{TiO}_{2}$ based composites made with recycled bags and polystyrene for the efficient removal of the 4-CP pesticide from drinking wate. Sep. Purif Technol. 2021, 270, 118821. [CrossRef]

20. De Assis, G.; Skovroinski, E.; Leite, V.D.; Rodrigues, M.O.; Galembeck, A.; Alves, M.F.; De Oliveira, R.J. Conversion of “Waste Plastic" into Photocatalytic Nanofoams for Environmental Remediation. ACS Appl. Mater. Interface 2018, 10, 8077-8085. [CrossRef]

21. Moura, M.M.M.S.; Lima, V.E.; Neto, A.M.; Lucena, A.L.A.; Napoleão, D.; Duarte, M.M.M.B. Degradation of the mixture of the ketoprofen, meloxicam and tenoxicam drugs using $\mathrm{TiO} 2 /$ metal photocatalysers supported in polystyrene packaging waste Water. Sci. Technol. 2021, 4, 863-876. [CrossRef]

22. Malara, A. Methods for Recycling Heterogenous Catalyst. Available online: https://encyclopedia.pub/10920 (accessed on 12 November 2021).

23. Zhang, H.; Ge, C.; Zhu, C.; Li, Y.; Tian, W.; Cheng, D.; Pan, Z. Deodorizing Properties of Photocatalyst Textiles and Its Effect Analysis. Phys. Procedia 2012, 25, 240-244. [CrossRef]

24. He, Z.; Lan, X.; Hu, Q.; Li, H.; Li, L.; Mao, J. Antifouling strategies based on super-phobic polymer material. Prog. Org. Coat. 2021, 157, 106285. [CrossRef] 
25. Mateos-Aparicio, P.; Rodriguez-Moreno, A. The Impact of Studying Brain Plasticity. Front. Cell. Neurosci. 2019, 13, 66. [CrossRef] [PubMed]

26. Camargo, P.H.; Satyanarayana, K.G.; Wypych, F. Nanocomposites: Synthesis, structure, properties and new application opportunitie. Mater. Res. 2009, 1, 1-39. [CrossRef]

27. Crawford, R.; Martin, P. Plastics Engineering, 4th ed.; Butterworth-Heinemann: Oxford, UK, 2020.

28. Bardají, D.K.R.; Moretto, J.A.S.; Furlan, J.P.R.; Stehling, E.G. A mini-review: Current advances in polyethylene bio-degradation. World J. Microbiol. Biotechnol. 2020, 36, 32. [CrossRef]

29. Haider, T.P.; Völker, C.; Kramm, J.; Landfester, K.; Wurm, F.R. Plastics of the Future? The Impact of Biodegradable Polymers on the Environment and on Society. Angew. Chem. Int. Ed. 2019, 58, 50-62. [CrossRef]

30. Proshad, R.; Kormoker, T.; Islam, S.; Haque, M.A.; Rahman, M.; Mithu, M.R. Toxic effects of plastic on human health and environment: A consequences of health risk assessment in Bangladesh. Int. J. Health 2017, 6, 1-5. [CrossRef]

31. Gahleitner, M.; Paulik, C. Polypropylene and Other Polyolefin. Brydson's Plast. Mater. 2017, 279-309. [CrossRef]

32. Maddah, H.A. Polypropylene as a Promising Plastic: A Review. J. Polym. Sci. 2016, 6, 1-11.

33. Rosa, D.S.; Guedes, G.F.; Carvalho, L. Processing and thermal, mechanical and morphological characterization of post-consumer polyolefins/thermoplastic starch blend. J. Mater. Sci. 2007, 42, 551-557. [CrossRef]

34. Andrade, B.T.N.; Bezerra, A.D.S.; Calado, R. Adding value to polystyrene waste by chemically transforming it into sulfonated polystyrene. Matéria (Rio de Janeiro) 2019, 24, 24. [CrossRef]

35. Sulong, N.H.R.; Mustapa, S.A.S.; Rashid, M.K.A. Application of expanded polystyrene (EPS) in buildings and constructions: A review. J. Appl. Polym. Sci. 2019, 136, 47529. [CrossRef]

36. Alabi, O.A.; Ologbonjaye, K.I.; Awosolu, O.; Alalade, O.A. Public and Environmental Health Effects of Plastic Wastes Disposal: A Review. Int. J. Toxicol. Risk Assess 2019, 5, 1-13.

37. Ojeda, T. Polymers and the Environment. Polym. Sci. 2013, 2013, 23.

38. Chowdhury, T.U.; Mahi, M.A.; Haque, K.A.; Rahman, M. A Review On The Use Of Polyethylene Terephthalate (Pet) As Aggregates In Concret. Malay J. Sci. 2018, 37, 118-136. [CrossRef]

39. Gewert, B.; Plassmann, M.M.; MacLeod, M. Pathways for degradation of plastic polymers floating in the marine environment. Environ. Sci. Proces Impacts 2015, 17, 1513-1521. [CrossRef]

40. Akshaya, E.; Palaniappan, R.; Sowmya; Rasana, N.; Jayanarayanan, K. Properties of Blends from Polypropylene and Recycled Polyethylene Terephthalate using a Compatibilize. In Materials Today: Proceedings; Elsevier BV: Amsterdam, The Netherlands, 2020; Volume 24, pp. 359-368.

41. Vervoort, S.; den Doelder, J.; Tocha, E.; Genoyer, J.; Walton, K.L.; Hu, Y.; Jeltsch, K. Compatibilization of polypropylenepolyethylene blend. Polym. Eng. Sci. 2017, 58, 460-465. [CrossRef]

42. Hubo, S.; Delva, L.; Van Damme, N.; Ragaert, K. Blending of recycled mixed polyolefins with recycled poly-propylene: Effect on physical and mechanical propertie. AIP Conf. Proc. 2016, 1779, 140006.

43. Dorigato, A. Recycling of polymer blend. Adv. Ind. Eng. Polym. Res. 2021, 4, 53-69. [CrossRef]

44. Aumnate, C.; Rudolph, N.; Sarmadi, M. Recycling of Polypropylene/Polyethylene Blends: Effect of Chain Structure on the Crystallization Behavior. Polymers 2019, 11, 1456. [CrossRef] [PubMed]

45. Aumnate, H.; Spicker, S.; Kiesel, R.; Samadi, M.; Rudolph, N. Recycling of PP/LDPE Blend: Miscibility, Thermal Properties, Rheological Behavior and Crystal Structur. Conf. SPE ANTEC 2016, 2016, 81-88.

46. Yin, S.; Tuladhar, R.; Shi, F.; Shanks, R.A.; Combe, M.; Collister, T. Mechanical Reprocessing of Polyolefin Waste: A Review. Polym. Eng. Sci. 2015, 2899-2909. [CrossRef]

47. Miandad, R.; Barakat, M.; Aburiazaiza, A.S.; Rehan, M.; Ismail, I.; Nizami, A. Effect of plastic waste types on pyrolysis liquid oil. Int. Biodeterio. Biodegrad. 2017, 119, 239-252. [CrossRef]

48. Kim, S.Y.; Meyer, H.W.; Saalwächter, K.; Zukoski, F. Polymer Dynamics in PEG-Silica Nanocomposites: Effects of Polymer Molecular Weight, Temperature and Solvent Dilution. Macromolecules 2012, 45, 4225-4237. [CrossRef]

49. Menard, K.P.; Menard, N.R. Dynamic Mechanical Analysis in the Analysis of Polymers and Rubber. Encycl. Polym. Sci. Technol. 2015, 2002, 1-33. [CrossRef]

50. Rogošić, M.; Mencer, H.; Gomzi, Z. Polydispersity index and molecular weight distributions of polymer. Eur. Polym. J. 1996, 32, 1337-1344. [CrossRef]

51. Danaei, M.; Dehghankhold, M.; Ataei, S.; Hasanzadeh Davarani, F.; Javanmard, R.; Dokhani, A.; Khorasani, S.; Mozafari, M.R. Impact of Particle Size and Polydispersity Index on the Clinical Applications of Lipidic Nanocarrier System. Pharmaceutics 2018, 10, 57. [CrossRef]

52. Stepto, R.F.T. Dispersity in polymer science (IUPAC Recommendations 2009). Pure Appl. Chem. 2009, 81, 351-353. [CrossRef]

53. Batista, N.L.; Olivier, P.; Bernhart, G.; Rezende, M.; Botelho, E. Correlation between degree of crystallinity, morphology and mechanical properties of PPS/carbon fiber laminate. Mater. Res. 2016, 19, 195-201. [CrossRef]

54. Uygunoğlu, T.; Güneş, I.; Brostow, W. Physical and Mechanical Properties of Polymer Composites with High Content of Wastes Including Boron. Mater. Res. 2015, 18, 1188-1196. [CrossRef]

55. Doyle, M.J. On the effect of crystallinity on the elastic properties of semicrystalline polyethylene. Polym. Eng. Sci. 2000, 40, 330-335. [CrossRef] 
56. Molnár, J.; Zuba, Z.; Sepsi, Ö.; Ujhelyi, F.; Erdei, G.; Lenk, S.; Menyhárd, A. Structural investigation of semicrystalline polymer. Polym. Test. 2021, 95, 107098. [CrossRef]

57. Stein, R.S.; Prud'Homme, R. Origin of polyethylene transparency. J. Polym. Sci. Part B Polym. Lett. 1971, 9, 595-598. [CrossRef]

58. Crawford, R.J.; Throne, J.L. Rotational molding polymers. Rotat. Molding Technol. 2002, 19-68. [CrossRef]

59. Jadhav, N.; Gaikwad, V.L.; Nair, K.; Kadam, H. Glass transition temperature: Basics and application in pharmaceutical sector. Asian J. Pharm. 2009, 3, 82. [CrossRef]

60. Roudaut, G.; Simatos, D.; Champion, D.; Contreras-Lopez, E.; Le Meste, M. Molecular mobility around the glass transition temperature: A mini review. Innov. Food Sci. Emerg. Technol. 2004, 5, 127-134. [CrossRef]

61. Wang, C.; Kondrashchenko, V.I.; Matseevich, A.V. Prediction of the coefficient of thermal expansion of building materials based on polyvinyl chlorid. J. Phys. Conf. Ser. 2019, 1425, 012094. [CrossRef]

62. Muthamilselvan, T.; Mondal, T. Thermally Conductive Plastics for Electronic Application. Ref. Modul. Mater. Sci. Mater. Eng. 2021. [CrossRef]

63. Ouyang, J. Application of intrinsically conducting polymers in flexible electronic. SmartMat 2021, 2, 263-285. [CrossRef]

64. Da Cunha, B.; Lopes, P.P.; Mayer, F.D.; Hoffmann, R. Assessment of Chemical and Mechanical Properties of Polymers Aiming to Replace the Stainless Steel in Distillation Column. Mater. Res. 2018, 21, 21. [CrossRef]

65. Baum, B.; Deanin, R.D. Controlled UV Degradation in Plastic. Polym. Technol. Eng. 1973, 2, 1-28. [CrossRef]

66. Markovičová, L.; Zatkalíková, V. The effect of UV aging on structural polymer. IOP Conf. Ser. Mater. Sci. Eng. 2019, 465, 012004. [CrossRef]

67. Teska, P.; Dayton, R.; Li, X.; Lamb, J.; Strader, P. Damage to Common healthcare. Polymer Surfaces from UV Exposure. Nano LIFE 2020, 10, 2050001. [CrossRef]

68. Chamas, A.; Moon, H.; Zheng, J.; Qiu, Y.; Tabassum, T.; Jang, J.H.; Suh, S. Degradation Rates of Plastics in the Environment. ACS Sustainable. Chem. Eng. 2020, 8, 3494-3511.

69. Paoli, M.A.D.; Waldman, W.R. Bio-based additives for thermoplastic. Polimeros 2019, 29, e2019030. [CrossRef]

70. Czogała, J.; Pankalla, E.; Turczyn, R. Recent Attempts in the Design of Efficient PVC Plasticizers with Reduced Migration. Materials 2021, 14, 844. [CrossRef]

71. Souza, D.H.S.; Andrade, T.; Dias, M.L. Effect of synthetic mica on the thermal properties of poly(lactic acid). Polimeros 2014, 24, 20-24. [CrossRef]

72. Hahladakis, J.N.; Velis, A.; Weber, R.; Iacovidou, E.; Purnell, P. An overview of chemical additives present in plastics: Migration, release, fate and environmental impact during their use, disposal and recycling. J. Hazard. Mater. 2018, 344, 179-199. [CrossRef]

73. Oldenziel, R.; Weber, H. Introduction: Reconsidering Recycling. Contemp. Eur Hist. 2013, 22, 347-370. [CrossRef]

74. Dogu, O.; Pelucchi, M.; Van de Vijver, R.; Van Steenberge, P.H.; D’Hooge, D.R.; Cuoci, A.; Mehl, M.; Frassoldati, A.; Faravelli, T.; Van Geem, K.M. The chemistry of chemical recycling of solid plastic waste via pyrolysis and gasification: State-of-the-art, challenges, and future direction. Prog. Energy Combust. Sci. 2021, 84, 100901. [CrossRef]

75. Lahtela, V.; Hyvärinen, M.; Kärki, T. Composition of Plastic Fractions in Waste Streams: Toward more. Efficient Recycling and Utilization. Polymers 2019, 11, 69. [CrossRef] [PubMed]

76. Ncube, L.; Ude, A.; Ogunmuyiwa, E.; Zulkifli, R.; Beas, I. An Overview of Plastic Waste Generation and Management in Food Packaging Industrie. Recycling 2021, 6, 12. [CrossRef]

77. Walker, T.R.; McGuinty, E.; Charlebois, S.; Music, J. Single-use plastic packaging in the Canadian food industry: Consumer behavior and perception Humanit. Soc. Sci. Commun. 2021, 8, 80. [CrossRef]

78. Chen, Y.; Awasthi, A.K.; Wei, F.; Tan, Q.; Li, J. Single-use plastics: Production, usage, disposal, and adverse impact. Sci. Total Environ. 2021, 752, 141772. [CrossRef] [PubMed]

79. Chabuk, A.; Al-Ansari, N.; Hussein, H.M.; Kamaleddin, S.; Knutsson, S.; Pusch, R.; Laue, J. Soil Characteristics in Selected Landfill Sites in the Babylon Governorate. Iraq. J. Civil Eng. Archit. 2017, 11, 348-363. [CrossRef]

80. Singh, N.; Hui, D.; Singh, R.; Ahuja, I.P.S.; Feo, L.; Fraternali, F. Recycling of plastic solid waste: A state of art review and future application. Compos. Part B Eng. 2017, 115, 409-422. [CrossRef]

81. Maris, J.; Bourdon, S.; Brossard, J.-M.; Cauret, L.; Fontaine, L.; Montembault, V. Mechanical recycling: Compatibilization of mixed thermoplastic waste. Polym. Degrad. Stab. 2018, 147, 245-266. [CrossRef]

82. Schyns, Z.O.G.; Shaver, M.P. Mechanical Recycling of Packaging Plastics: A Review. Macromol. Rapid Commun. 2021, 42 , e2000415. [CrossRef]

83. Jubinville, D.; Esmizadeh, E.; Tzoganakis, C.; Mekonnen, T. Thermo-mechanical recycling of polypropylene for the facile and scalable fabrication of highly loaded wood plastic composite. Compos. Part B Eng. 2021, 219, 108873. [CrossRef]

84. Thiounn, T.; Smith, R. Advances and approaches for chemical recycling of plastic waste. J. Appl. Polym. Sci. 2020, 58, 1347-1364. [CrossRef]

85. Almeida, D.; Marques, M.D.F. Thermal and catalytic pyrolysis of plastic waste. Polímeros 2016, 26, 44-51. [CrossRef]

86. Grigore, M.E. Methods of Recycling, Properties and Applications of Recycled Thermoplastic Polymer. Recycling 2017, 2, 24. [CrossRef]

87. Hopewell, J.; Dvorak, R.; Kosior, E. Plastics recycling: Challenges and opportunities. Philo Tran R. Soc. B Biol. Sci. 2009, 364, 2115-2126. [CrossRef] [PubMed] 
88. Li, N.; Liu, H.; Cheng, Z.; Yan, B.; Chen, G.; Wang, S. Conversion of plastic waste into fuels: A critical review. J. Hazard. Mater. 2022, 424, 127460. [CrossRef]

89. Ahmad, N.; Ahmad, N.; Maafa, I.M.; Ahmed, U.; Akhter, P.; Shehzad, N.; Amjad, U.-E.-S.; Hussain, M. Thermal conversion of polystyrene plastic waste to liquid fuel via ethanolysis. Fuel 2020, 279, 118498. [CrossRef]

90. Power Technology. Turning Waste into Power: The Plastic to Fuel Project. Available online: https://www.powertechnology.com/ comment/plastic-to-fuel/ (accessed on 7 December 2021).

91. Jha, K.K.; Kannan, T. Recycling of plastic waste into fuel by pyrolysis-A review. Mater. Today Proc. 2021, 37, 3718-3720. [CrossRef]

92. Nakaji, Y.; Tamura, M.; Miyaoka, S.; Kumagai, S.; Tanji, M.; Nakagawa, Y.; Tomishige, K. Low-Temperature Catalytic Upgrading of Waste Polyolefinic Plastics into Liquid Fuels and Waxes. Appl. Catal. B Environ. 2020, 285, 119805. [CrossRef]

93. Christopher, F.J.; Kumar, P.S.; Vo, D.-V.N.; Christopher, F.C.; Jayaraman, L. Methods for chemical conversion of plastic wastes into fuels and chemicals. A review. Environ. Chem. Lett. 2021. [CrossRef]

94. Jha, K.K.; Kannan, T.; Chandradass, J.; Wilson, D.V.H.; Das, A. Analysis and simulation of mini pyrolysis reactor for conversion of plastic waste into fuel. Mater. Today Proc. 2021, 45, 7166-7170. [CrossRef]

95. Miandad, R.; Rehan, M.; Barakat, M.A.; Aburiazaiza, A.S.; Khan, H.; Ismail, I.M.I.; Dhavamani, J.; Gardy, J.; Hassanpour, A.; Nizami, A.-S. Catalytic Pyrolysis of Plastic Waste: Moving Toward Pyrolysis Based Biorefineries. Front. Energy Res. $2019,7$. [CrossRef]

96. Kedzierski, M.; Frère, D.; Le Maguer, G.; Bruzaud, S. Why is there plastic packaging in the natural environment? Under-standing the roots of our individual plastic waste management behavior. Sci. Total Environ. 2020, 740, 139985. [CrossRef] [PubMed]

97. Sadat-Shojai, M.; Bakhshandeh, G.-R. Recycling of PVC waste. Polym. Degrad. Stab. 2011, 96, 404-415. [CrossRef]

98. North, E.J.; Halden, R.U. Plastics and environmental health: The road ahead. Rev. Environ. Health 2013, 28, 1-8. [CrossRef] [PubMed]

99. Ferronato, N.; Torretta, V. Waste Mismanagement in Developing Countries: A Review of Global Issue. Int. J. Environ. Res. Public Health 2019, 16, 1060. [CrossRef] [PubMed]

100. Sari, D.A.A.; Suryanto; Sudarwanto, A.S.; Nugraha, S.; Utomowati, R. Reduce marine debris policy in Indonesia. IOP Conf. Ser Earth Environ. Sci. 2021, 724, 012118. [CrossRef]

101. Verma, R.; Vinoda, K.S.; Papireddy, M.; Gowda, A.N.S. Toxic Pollutants from Plastic Waste-A Review. Procedia Environ. Sci. 2016, 35, 701-708. [CrossRef]

102. Martinez, W. How science and technology developments impact employment and education. Proc. Natl. Acad. Sci. USA 2018, 115, 12624-12629. [CrossRef]

103. Mitchell, S.; Qin, R.; Zheng, N.; Pérez-Ramírez, J. Nanoscale engineering of catalytic materials for sustainable technologies. Nat. Nanotechnol. 2020, 16, 1-11. [CrossRef]

104. Mishra, R.; Militky, J. Future outlook in the context of nanoscale textiles as a technology for the twenty-first century. Nanotechnol. Text. 2019, 387-388. [CrossRef]

105. Kumar, K.; Chowdhury, A. Nanoscale Heterogeneity in Amorphous and Semi-Crystalline Materials: A Technical Perspective. In Reference Module in Materials Science and Materials Engineering; Elsevier: Amsterdam, The Netherlands, 2021. [CrossRef]

106. Jeevanandam, J.; Barhoum, A.; Chan, Y.S.; Dufresne, A.; Danquah, M.K. Review on nanoparticles and nanostructured materials: History, sources, toxicity and regulation. Beilstein J. Nanotechnol. 2018, 9, 1050-1074. [CrossRef] [PubMed]

107. Danish, M.S.S.; Estrella, L.L.; Alemaida, I.M.A.; Lisin, A.; Moiseev, N.; Ahmadi, M.; Senjyu, T. Photocatalytic Applications of Metal Oxides for Sustainable Environmental Remediation. Metal 2021, 11, 80. [CrossRef]

108. Baig, N.; Kammakakam, I.; Falath, W. Nanomaterials: A review of synthesis methods, properties, recent progress, and challenge. Mater. Adv. 2021, 2, 1821-1871. [CrossRef]

109. García-Quintero, A.; Palencia, M. A critical analysis of environmental sustainability metrics applied to green synthesis of nanomaterials and the assessment of environmental risks associated with the nanotechnology. Sci. Total Environ. 2021, 793, 148524. [CrossRef]

110. Saleh, T.A. Nanomaterials: Classification, properties, and environmental toxicities. Environ. Technol. Innov. 2020, $20,101067$. [CrossRef]

111. Gottardo, S.; Mech, A.; Drbohlavová, J.; Małyska, A.; Bøwadt, S.; Riego Sintes, J.; Rauscher, H. Towards safe and sus-tainable innovation in nanotechnology: State-of-play for smart nanomaterial. NanoImpact 2021, 21, 100297. [CrossRef]

112. Khalaj, M.; Kamali, M.; Costa, M.E.V.; Capela, I. Green synthesis of nanomaterials-A scientometric assessment. J. Clean. Prod. 2020, 267, 122036. [CrossRef]

113. De Jesus, R.A.; De Assis, G.; De Oliveira, R.J.; Costa, J.A.S.; Da Silva, M.P.; Bilal, M.; Figueiredo, R.T. Environ-mental remediation potentialities of metal and metal oxide nanoparticles: Mechanistic biosynthesis, influencing factors, and application standpoint. Environ. Technol. Innov. 2021, 24, 1-21. [CrossRef]

114. Li, X.; Xu, H.; Chen, Z.-S.; Chen, G. Biosynthesis of Nanoparticles by Microorganisms and Their Application. J. NanoMater. 2011, 2011, 1-16. [CrossRef]

115. Guilger-Casagrande, M.; Lima, R. Synthesis of Silver Nanoparticles Mediated by Fungi: A Review Front. Bioeng. Biotecnol. 2019, 7, 1-16. [CrossRef]

116. Kuppusamy, P.; Yusoff, M.M.; Maniam, G.P.; Govindan, N. Biosynthesis of metallic nanoparticles using plant deriva-tives and their new avenues in pharmacological application-An updated report. Saudi Pharm J. 2016, 24, 473-484. [CrossRef] 
117. Bolade, O.P.; Williams, A.B.; Benson, N.U. Green synthesis of iron-based nanomaterials for environmental remediation: A review. Environ. Nanotechnol. Monit. Manag. 2020, 13, 100279. [CrossRef]

118. Goswami, A.D.; Trivedi, D.H.; Jadhav, N.L.; Pinjari, D.V. Sustainable and green synthesis of carbon nanomaterials: A review. J. Environ. Chem. Eng. 2021, 9, 106118. [CrossRef]

119. Fleischer, T.; Grunwald, A. Making nanotechnology developments sustainable A role for technology assessment? J. Clean. Prod. 2008, 16, 889-898. [CrossRef]

120. Tom, A.P. Nanotechnology for sustainable water treatment-A review. Mater. Today Proc. 2021, 1-6. [CrossRef]

121. Diallo, M.S.; Fromer, N.A.; Jhon, M.S. Nanotechnology for sustainable development: Retrospective and outlook. J. Nanoparticle Res. 2013, 15, 1-16. [CrossRef]

122. Moore, K.; Wei, W. Applications of carbon nanomaterials in perovskite solar cells for solar energy conversion. Nano Mater. Sci. 2021, 3, 276-290. [CrossRef]

123. Hu, J.; Xiong, X.; Guan, W.; Long, H. Recent advances in carbon nanomaterial-optimized perovskite solar cell. Mater. Today Energy 2021, 21, 100769. [CrossRef]

124. Deshmukh, M.A.; Park, S.-J.; Hedau, B.S.; Ha, T.-J. Recent progress in solar cells based on carbon nanomaterial. Sol. Energy 2021, 220, 953-990. [CrossRef]

125. Qi, H.; Xu, Y.; Hu, P.; Yao, C.; Yang, D. Construction and applications of DNA-based nanomaterials in cancer therapy. Chin. Chem. Lett. 2021, 1-14. [CrossRef]

126. Murali, A.; Lokhande, G.; Deo, K.A.; Brokesh, A.; Gaharwar, A.K. Emerging 2D nanomaterials for biomedical application. Mater. Today 2021, 2021, 1-27. [CrossRef]

127. Damodharan, J. Nanomaterials in medicine-An overview. Mater. Today Proc. 2020, 37, 383-385. [CrossRef]

128. Kang, Y.; Yu, F.; Zhang, L.; Wang, W.; Chen, L.; Li, Y. Review of ZnO-based nanomaterials in gas sensor. Solid State Ion. 2021, 360, 115544. [CrossRef]

129. Ahmad, R.; Majhi, S.M.; Zhang, X.; Swager, T.M.; Salama, K.N. Recent progress and perspectives of gas sensors based on vertically oriented ZnO nanomaterial. Adv. Colloid Interface Sci. 2019, 270, 1-27. [CrossRef] [PubMed]

130. Thai, N.X.; Tonezzer, M.; Masera, L.; Nguyen, H.; Van Duy, N.; Hoa, N.D. Multi gas sensors using one nanomaterial, temperature gradient, and machine learning algorithms for discrimination of gases and their concentration. Anal. Chim. Acta 2020, 1124, 85-93. [CrossRef] [PubMed]

131. Share, K.; Westover, A.; Li, M.; Pint, L. Surface engineering of nanomaterials for improved energy storage-A review. Chem. Eng. Sci. 2016, 154, 3-19. [CrossRef]

132. Zhu, Y.; Peng, L.; Fang, Z.; Yan, C.; Zhang, X.; Yu, G. Structural Engineering of 2D Nanomaterials for Energy Storage and Catalysis. Adv. Mater. 2018, 30, e1706347. [CrossRef] [PubMed]

133. Nayak, A.; Saini, V.K.; Bhushan, B. Chapter Nanomaterials for Energy Harvesting and Storage: An Overview. Appl. Nanomater. Agric. Food Sci. Med. 2021, 16, 188-203. [CrossRef]

134. Pomerantseva, E.; Bonaccorso, F.; Feng, X.; Cui, Y.; Gogotsi, Y. Energy storage: The future enabled by nanomaterial. Science 2019, 366, eaan8285. [CrossRef] [PubMed]

135. Li, H.; Zhou, X.; Zhai, W.; Lu, S.; Liang, J.; He, Z.; Long, H.; Xiong, T.; Sun, H.; He, Q.; et al. Phase Engineering of Nanomaterials for Clean Energy and Catalytic Application. Adv. Energy Mater. 2020, 10, 2002019. [CrossRef]

136. Khalil, M.; Kadja, G.T.; Ilmi, M.M. Advanced nanomaterials for catalysis: Current progress in fine chemical synthesis, hydrocarbon processing, and renewable energy. J. Ind. Eng. Chem. 2021, 93, 78-100. [CrossRef]

137. Jangid, P.; Inbaraj, M.P. Applications of nanomaterials in wastewater treatment. Mater. Today Proc. 2021, 43, 2877-2881. [CrossRef]

138. Alidokht, L.; Anastopoulos, I.; Ntarlagiannis, D.; Soupios, P.; Tawabini, B.; Kalderis, D.; Khataee, A. Recent advances in the application of nanomaterials for the remediation of arsenic-contaminated water and soil. J. Environ. Chem. Eng. 2021, 9, 105533. [CrossRef]

139. Sridevi, M.; Nirmala, C.; Jawahar, N.; Arthi, G.; Vallinayagam, S.; Sharma, V.K. Role of nanomaterial's as adsorbent for heterogeneous reaction in waste water treatment. J. Mol. Struct. 2021, 1241, 130596. [CrossRef]

140. Anwar, J.; Dipak, V.; Shirish, H.; Bharat, A.; Javed, S.; Mika, S. Cellulose-based nanomaterials for water and wastewater treatments: A review. J. Environ. Chem. Eng. 2021, 9, 106626.

141. Cheng, K.; Lim, J.-W.; Adhikari, S. Converting solid biomass waste into nanomaterial for the treatment of hazardous waste. Chemosphere 2021, 285, 131461. [CrossRef]

142. Tamsilian, Y.; Shirazi, M.; Rad, G.M. Nanomaterial-Incorporated Polymer Composites for Industrial Effluent: From Syn-thesis to Application. Encycl. Mater. Compos. 2021, 1, 998-1012.

143. Kumar, J.A.; Krithiga, T.; Manigandan, S.; Sathish, S.; Renita, A.A.; Prakash, P.; Naveen Prasad, B.S.; Praveen Kumar, T.R.; Rajasimman, M.; Hosseini-Bandegharaei, A.; et al. A focus to green synthesis of metal/metal based ox-ide nanoparticles: Various mechanisms and applications towards ecological approach. J. Clean. Prod. 2021, 324, 129198. [CrossRef]

144. Badri, A.; Slimi, S.; Guergueb, M.; Kahri, H.; Mateos, X. Green synthesis of copper oxide nanoparticles using Prickly Pear peel fruit extract: Characterization and catalytic activity. Inorg. Chem. Commun. 2021, 134, 109027. [CrossRef]

145. Cruz, D.R.; de Jesus, G.K.; Santos, A.; Silva, W.R.; Wisniewski, A.; Cunha, G.; Romão, L.P. Magnetic nanostructured material as heterogeneous catalyst for degradation of AB210 dye in tannery wastewater by electro-Fenton process. Chemosphere 2021, 280, 130675. [CrossRef] 
146. Liu, D.; Yang, N.; Zeng, Q.; Liu, H.; Chen, D.; Cui, P.; Xu, L.; Hu, C.; Yang, J. Core-shell Ag-Pt nanoparticles: A versatile platform for the synthesis of heterogeneous nanostructures towards catalyzing electrochemical reaction. Chin. Chem. Lett. 2021, 2021, 1-14. [CrossRef]

147. Soares, L.G.; Vaz, M.D.O.; Teixeira, S.R.; Alves, A.K. Absorbance determination and photocatalytic production of hydrogen using tungsten and $\mathrm{TiO} 2$ oxide nanostructures As catalyst. Clean. Eng. Technol. 2021, 5, 100268. [CrossRef]

148. Miceli, M.; Frontera, P.; Macario, A.; Malara, A. Recovery/Reuse of Heterogeneous Supported Spent Catalyst. Catalysts 2021, 11, 591. [CrossRef]

149. Malakar, A.; Kanel, S.R.; Ray, C.; Snow, D.D.; Nadagouda, M.N. Nanomaterials in the environment, human exposure pathway, and health effects: A review. Sci. Total. Environ. 2020, 759, 143470. [CrossRef]

150. Korani, M.; Ghazizadeh, E.; Korani, S.; Hami, Z.; Mohammadi-Bardbori, A. Effects of silver nanoparticles on human health. Eur. J. Nanomed. 2015, 7, 51-62. [CrossRef]

151. Jaswal, T.; Gupta, J. A review on the toxicity of silver nanoparticles on human health. Mater. Today Proc. 2021, 2021, 1-5. [CrossRef]

152. Medici, S.; Peana, M.; Pelucelli, A.; Zoroddu, M.A. An updated overview on metal nanoparticles toxicity. Semin. Cancer Biol. 2021, 76, 17-26. [CrossRef]

153. Atmianlu, P.A.; Badpa, R.; Aghabalaei, V.; Baghdadi, M. A review on the various beds used for immobilization of nanoparticles: Overcoming the barrier to nanoparticle applications in water and wastewater treatment. J. Environ. Chem. Eng. 2021, 9, 106514. [CrossRef]

154. Wang, H.; Zhuang, M.; Shan, L.; Wu, J.; Quan, G.; Cui, L.; Yan, J. Bimetallic FeNi nanoparticles immobilized by bio-mass-derived hierarchically porous carbon for efficient removal of $\mathrm{Cr}$ (VI) from aqueous solution. J. Hazard. Mater. 2022, 423, 127098. [CrossRef]

155. Prasad, R.; Bhattacharyya, A.; Nguyen, Q.D. Nanotechnology in Sustainable Agriculture: Recent Developments, Challenges, and Perspective. Front. Microbiol. 2017, 8, 1014. [CrossRef]

156. Wu, Q.; Miao, W.-S.; Zhang, Y.-D.; Gao, H.-J.; Hui, D. Mechanical properties of nanomaterials: A review. Nanotechnol. Rev. 2020, 9 , 259-273. [CrossRef]

157. Reghunath, S.; Pinheiro, D.; Kr, S.D. A review of hierarchical nanostructures of TiO2: Advances and application. Appl. Sur Sci. Adv. 2021, 3, 100063. [CrossRef]

158. Bozon-Verduraz, F.; Fiévet, F.; Piquemal, J.-Y.; Brayner, R.; El Kabouss, K.; Soumare, Y.; Viau, G.; Shafeev, G. Nanoparticles of metal and metal oxides: Some peculiar synthesis methods, size and shape control, application to catalysts preparation. Braz. J. Phys. 2009, 39, 134-140. [CrossRef]

159. Kanniah, P.; Chelliah, P.; Thangapandi, J.R.; Thangapandi, E.J.S.B.; Kasi, M.; Sivasubramaniam, S. Chapter Benign fabrication of metallic/metal oxide nanoparticles from alga. In Nanobiotechnology for Plant Protection: Agri-Waste and Microbes for Production of Sustainable Nanomaterial; Abd-Elsalam, K.A., Periakaruppan, R., Rajeshkuma, S., Eds.; Elsevier: Amsterdam, The Netherlands, 2022; pp. 465-493.

160. Yaqoob, A.A.; Ahmad, H.; Parveen, T.; Ahmad, A.; Oves, M.; Ismail, I.M.I.; Qari, H.A.; Umar, K.; Ibrahim, M.N.M. Recent Advances in Metal Decorated Nanomaterials and Their Various Biological Applications: A Review. Front. Chem. $2020,8,341$. [CrossRef]

161. Ashik, U.P.M.; Kudo, S.; Hayashi, J. Chapter 2. An Overview of Metal Oxide Nanostructures. Synth. Inorg. Nanomater. 2018, 19-57. [CrossRef]

162. Rao, V.N.; Malu, T.J.; Cheralathan, K.K.; Sakar, M.; Pitchaimuthu, S.; Rodríguez-González, V.; Kumari, M.M.; Shankar, M.V. Light-driven transformation of biomass into chemicals using photocatalysts-Vistas and challenge. J. Environ. Manag. 2021, 284, 111983. [CrossRef]

163. Srivastava, N.; Srivastava, M.; Mishra, P.; Kausar, M.A.; Saeed, M.; Gupta, V.K.; Singh, R.; Ramteke, P. Advances in nanomaterials induced biohydrogen production using waste biomas. Bioresou Technol. 2020, 307, 123094. [CrossRef]

164. Nwosu, U.; Wang, A.; Palma, B.; Zhao, H.; Khan, M.A.; Kibria, M.; Hu, J. Selective biomass photoreforming for valuable chemicals and fuels: A critical review. Renew. Sustain. Energy Rev. 2021, 148, 111266. [CrossRef]

165. Ma, J.; Jin, D.; Li, Y.; Xiao, D.; Jiao, G.; Liu, Q.; Guo, Y.; Xiao, L.; Chen, X.; Li, X.; et al. Photocatalytic conversion of biomass-based monosaccharides to lactic acid by ultrathin porous oxygen doped carbon nitrid. Appl. Catal. B Environ. 2021, 283, 119520. [CrossRef]

166. Terna, A.D.; Elemike, E.E.; Mbonu, J.I.; Osafile, O.E.; Ezeani, R.O. The future of semiconductors nanoparticles: Synthesis, properties and application Mater. Sci. Eng. B 2021, 272, 1-24. [CrossRef]

167. Rastogi, A.; Zivcak, M.; Sytar, O.; Kalaji, H.M.; He, X.; Mbarki, S.; Brestic, M. Impact of Metal and Metal Oxide Nano-particles on Plant: A Critical Review. Front. Chem. 2017, 5, 78. [CrossRef]

168. Mourdikoudis, S.; Pallares, R.M.; Thanh, N.T.K. Characterization techniques for nanoparticles: Comparison and complementarity upon studying nanoparticle properties. Nanoscale 2018, 10, 12871-12934. [CrossRef]

169. Ramalingam, G.; Kathirgamanathan, P.; Ravi, G.; Elangovan, T.; Kumar, B.A.; Manivannan, N.; Kasinathan, K. Quantum Confinement Effect of 2D NanomaterialS; Quantum Dots-Fundamental and Applications, Faten Divsar; IntechOpen: London, UK, 2020; Available online: https:/ / www.intechopen.com/chapters/70534 (accessed on 12 November 2021). [CrossRef]

170. Aghamirzaei, M.; Khiabani, M.S.; Hamishehkar, H.; Mokarram, R.R.; Amjadi, M. Antioxidant, antimicrobial and cytotoxic activities of biosynthesized gold nanoparticles (AuNPs) from Chinese lettuce (CL) leave extract (Brassica rapa va pekinensis). Mater. Today Commun. 2021, 29, 102831. [CrossRef] 
171. Ezealigo, U.S.; Ezealigo, B.N.; Aisida, S.O.; Ezema, F.I. Iron oxide nanoparticles in biological systems: Antibacterial and toxicology perspective. JCIS Open 2021, 4, 100027. [CrossRef]

172. Patil, M.P.; Seong, Y.-A.; Kim, J.-O.; Seo, Y.B.; Kim, G.-D. Synthesis of silver nanoparticles using aqueous extract of Cuscuta japonica seeds and their antibacterial and antioxidant activitie. Inorg. Chem. Commun. 2021, 109035. [CrossRef]

173. Cizmar, T.; Panzic, I.; Capan, I.; Gajović, A. Nanostructured $\mathrm{TiO}_{2}$ photocatalyst modified with Cu for improved imidacloprid degradation. Appl. Sur. Sci. 2021, 569, 151026. [CrossRef]

174. Ma, Y.; Xu, T.; Li, L.; Wang, J.; Li, Y.; Zhang, H. Core-shell nanostructure $\alpha-\mathrm{Fe}_{2} \mathrm{O}_{3} / \mathrm{SnO}_{2}$ binary oxides for the catalytic ox-idation and adsorption of elemental mercury from flue gas. J. Environ. Chem. Eng. 2021, 9, 105137. [CrossRef]

175. Hoang, T.T.N.; Lin, Y.-S.; Le, T.N.H.; Le, T.K.; Huynh, T.K.X.; Tsai, D.-H. Cu-ZnO@ $\mathrm{Al}_{2} \mathrm{O}_{3}$ hybrid nanoparticle with enhanced activity for catalytic $\mathrm{CO}_{2}$ conversion to methanol. Adv. Powder Technol. 2021, 32, 1785-1792. [CrossRef]

176. Nandanapalli, K.R.; Mudusu, D.; Lingandhinne, R.M.R.; Lee, S.W. Passivation layeredependent catalysis of zinc oxide nanostructure. Mater. Today Chem. 2021, 22, 100592. [CrossRef]

177. Damian, C.; Necolau, M.; Neblea, I.; Vasile, E.; Iovu, H. Synergistic effect of graphene oxide functionalized with $\mathrm{SiO}_{2}$ nanostructures in the epoxy nanocomposite. Appl. Sur Sci. 2020, 507, 145046. [CrossRef]

178. Minakshi, M.; Blackford, M.; Ionescu, M. Characterization of alkaline-earth oxide additions to the $\mathrm{MnO}_{2}$ cathode in an aqueous secondary battery. J. Alloy. Compd. 2011, 509, 5974-5980. [CrossRef]

179. Minakshi, M.; Mitchell, D.R.G.; Munnangi, A.R.; Barlow, A.J.; Fichtner, M. New insights into the electro-chemistry of magnesium molybdate hierarchical architectures for high performance sodium device. Nanoscale 2018, 10, 13277-13288. [CrossRef] [PubMed]

180. Dragomir, M. Metallic Nanoparticle. Available online: https://sabotin.ung.si/ \{\}sstanic/teaching/Seminar/2009/20091214_ Dragomir_MetNP.pd (accessed on 8 November 2021).

181. Narayan, N.; Meiyazhagan, A.; Vajtai, R. Metal Nanoparticles as Green Catalysts. Materials 2019, 12, 3602. [CrossRef]

182. Goniakowski, J. Noguera, Insulating oxide surfaces and nanostructure. Comptes Rendus Phys. 2016, 17, 471-480. [CrossRef]

183. Issa, B.; Obaidat, I.M.; Albiss, B.A.; Haik, Y. Magnetic Nanoparticles: Surface Effects and Properties Related to Biomedicine Application. Int. J. Mol. Sci. 2013, 14, 21266-21305. [CrossRef] [PubMed]

184. Rhaman, M.; Matin, M.; Hakim, M.; Islam, M. Optical and electrical properties of impurity-less multiferroic bismuth ferrite nanoparticle. Mater. Sci. Eng. B 2021, 275, 115501. [CrossRef]

185. Yuan, S.; Duan, X.; Liu, J.; Ye, Y.; Lv, F.; Liu, T.; Zhang, X. Recent progress on transition metal oxides as advanced mate-rials for energy conversion and storage. Energy Storage Mater. 2021, 42, 317-369. [CrossRef]

186. Miller, D.R.; Akbar, S.A. Nano-Heterostructure Metal Oxide Gas Sensors: Opportunities and Challenge. Ref. Modul. Mater. Sci. Mater. Eng. 2022, 3, 297-301.

187. Hassan, I.U.; Salim, H.; Naikoo, G.A.; Awan, T.; Dar, R.A.; Arshad, F.; Qurashi, A. A review on recent advances in hi-erarchically porous metal and metal oxide nanostructures as electrode materials for supercapacitors and non-enzymatic glucose sensor. $J$. Saudi Chem. Soc. 2021, 25, 101228. [CrossRef]

188. Chavali, M.S.; Nikolova, M.P. Metal oxide nanoparticles and their applications in nanotechnology. SN Appl. Sci. 2019, 1, 607. [CrossRef]

189. Adekoya, J.A.; Ogunniran, K.O.; Siyanbola, T.O.; Dare, E.O.; Revaprasadu, N. Band Structure, Morphology, Functionality, and Size-Dependent Properties of Metal Nanoparticle. In Noble and Precious Metals_Properties, Nanoscale Effects and Applications; Seehra, M.S., Bristow, A.D., Eds.; IntechOpen: London, UK, 2018; pp. 15-42. Available online: https://www.intechopen.com/ chapters /58870 (accessed on 12 November 2021). [CrossRef]

190. Naseem, T.; Durrani, T. The role of some important metal oxide nanoparticles for wastewater and antibacterial applications: A review. J. Environ. Chem. Ecotoxicol. 2021, 3, 59-75. [CrossRef]

191. Aragaw, T.A.; Bogale, F.M.; Aragaw, B.A. Iron-based nanoparticles in wastewater treatment: A review on synthesis methods, applications, and removal mechanism. J. Saudi Chem. Soc. 2021, 25, 101280. [CrossRef]

192. Nwanya, A.; Razanamahandry, L.; Bashir, A.; Ikpo, O.; Nwanya, S.; Botha, S.; Ntwampe, S.; Ezema, F.I.; Iwuoha, E.; Maaza, M. Industrial textile effluent treatment and antibacterial effectiveness of Zea mays L. Dry husk mediated bio-synthesized copper oxide nanoparticle. J. Hazard. Mater. 2019, 375, 281-289. [CrossRef]

193. Ragothaman, M.; Mekonnen, B.T.; Palanisamy, T. Synthesis of magnetic Fe-Cr bimetallic nanoparticles from industrial effluents for smart material application. Mater. Chem. Phys. 2020, 253, 123405. [CrossRef]

194. Jeevanandam, P.; Klabunde, K.J. Chapter 14. Adsorbents. Synthesis, Properties, and Applications of Oxide Nanomaterials; Rodriguez, J.A., Fernández-Garcia, M., Eds.; John Wiley \& Sons: Hoboken, NJ, USA, 2007; p. 383. ISBN 978-0-471-72405-6.

195. Xu, L.-H.; Patil, D.S.; Yang, J.; Xiao, J. Metal Oxide Nanostructures: Synthesis, Properties, and Application. J. Nanotechnol. 2015, 2015, 1-2. [CrossRef]

196. Ndolomingo, M.J.; Bingwa, N.; Meijboom, R. Review of supported metal nanoparticles: Synthesis methodologies, advantages and application as catalyst. J. Mater. Sci. 2020, 55, 6195-6241. [CrossRef]

197. Lofrano, G.; Carotenuto, M.; Libralato, G.; Domingos, R.F.; Markus, A.; Dini, L.; Meric, S. Polymer functionalized nanocomposites for metals removal from water and wastewater: An overview. Water Res. 2016, 92, 22-37. [CrossRef] [PubMed]

198. Dale, A.L.; Casman, E.A.; Lowry, G.V.; Lead, J.R.; Viparelli, E.; Baalousha, M. Modeling Nanomaterial Environmental Fate in Aquatic System. Environ. Sci. Technol. 2015, 49, 2587-2593. [CrossRef] [PubMed] 
199. Nasrollahzadeh, M.; Soleimani, F.; Bidgoli, N.S.S.; Nezafat, Z.; Orooji, Y.; Baran, T. Recent developments in polymer-supported ruthenium nanoparticles/complexes for oxidation reaction. J. Organomet. Chem. 2021, 933, 121658. [CrossRef]

200. Njuguna, J.; Pielichowski, K.; Zhu, H. Health and Environmental Safety of Nanomaterial Polymer Nanocomposites and Other Materials Containing Nanoparticle; Elsevier: Amsterdam, The Netherlands, 2021; eBook; ISBN 9780128205105.

201. Hu, Z.-P.; Wang, Z.; Yuan, Z.-Y. Cr/ $\mathrm{Al}_{2} \mathrm{O}_{3}$ catalysts with strong metal-support interactions for stable catalytic dehydro-genation of propane to propylene. Mol. Catal. 2020, 493, 111052. [CrossRef]

202. Neppolian, B.; Mine, S.; Horiuchi, Y.; Bianchi, C.L.; Matsuoka, M.; Dionysiou, D.D.; Anpo, M. Efficient photocatalytic degradation of organics present in gas and liquid phases using Pt-TiO 2 /Zeolite (H-ZSM). Chemosphere 2016, 153, 237-243. [CrossRef] [PubMed]

203. Jiang, N.; Shang, R.; Heijman, S.G.J.; Rietveld, L.C. High-silica zeolites for adsorption of organic micro-pollutants in water treatment: A review. Water Res. 2018, 144, 145-161. [CrossRef] [PubMed]

204. Du, J.-T.; Niu, H.; Wu, H.; Zeng, X.-F.; Wang, J.-X.; Chen, J.-F. PVP-stabilized platinum nanoparticles supported on mod-ified silica spheres as efficient catalysts for hydrogen generation from hydrolysis of ammonia borane. Int. J. Hydrogen Energy 2021, 46, 25081-25091. [CrossRef]

205. Karaboğa, S. Tungsten(VI) oxide supported rhodium(0) nanoparticles; highly efficient catalyst for $\mathrm{H}_{2}$ production from dimethylamine borane. Int. J. Hydrogen Energy 2021, 46, 17763-17775. [CrossRef]

206. Böhm, D.; Beetz, M.; Gebauer, C.; Bernt, M.; Schröter, J.; Kornherr, M.; Zoller, F.; Bein, T.; Fattakhova-Rohlfing, D. Highly conductive titania supported iridium oxide nanoparticles with low overall iridium density as OER catalyst for large-scale PEM electrolysis. Appl. Mater. Today 2021, 24, 101134. [CrossRef]

207. Zheng, W.; Yang, W.; He, G.; Chi, J.; Duan, Y.; Chen, M.; Tian, M. Facile synthesis of extremely small $\mathrm{Ag}_{3} \mathrm{PO}_{4}$ nanoparticles on hierarchical hollow silica sphere (HHSS) for the enhanced visible-light photocatalytic property and stability. Colloids Surf. A 2019, 571, 1-8. [CrossRef]

208. Orooji, Y.; Akbari, Z.; Nezafat, Z.; Nasrollahzadeh, M.; Kamali, T.A. Recent signs of progress in polymer-supported silver complexes/nanoparticles for remediation of environmental pollutants. J. Mol. Liq. 2021, 329, 115583. [CrossRef]

209. Oun, A.; Tahri, N.; Mahouche-Chergui, S.; Carbonnier, B.; Majumdar, S.; Sarkar, S.; Sahoo, G.C.; Ben Amar, R. Tubular ultrafiltration ceramic membrane based on titania nanoparticles immobilized on macroporous clay-alumina support: Elaboration, characterization and application to dye removal. Sep. Purif. Technol. 2017, 188, 126-133. [CrossRef]

210. Oton, L.F.; Oliveira, A.C.; de Araujo, J.C.S.; Araujo, R.S.; de Sousa, F.F.; Saraiva, G.D.; Lang, R.; Otubo, L.; Duarte, G.C.D.S.; Campos, A. Selective catalytic reduction of NOx by CO (CO-SCR) over metal-supported nanoparticles dispersed on porous alumina. Adv. Powder Technol. 2020, 31, 464-476. [CrossRef]

211. Poupart, R.; Grande, D.; Carbonnier, B.; Le Droumaguet, B. Porous polymers and metallic nanoparticles: A hybrid wed-ding as a robust method toward efficient supported catalytic systems. Prog. Polym. Sci. 2019, 96, 21-42. [CrossRef]

212. Sarkar, S.; Guibal, E.; Quignard, F.; Sengupta, A.K. Polymer-supported metals and metal oxide nanoparticles: Synthesis, characterization, and applications. J. Nanoparticle Res. 2012, 14, 1-24. [CrossRef]

213. Singh, S.; Naik, T.S.S.K.; Anil, A.G.; Dhiman, J.; Kumar, V.; Dhanjal, D.S.; Aguilar-Marcelino, L.; Singh, J.; Ramamurthy, P.C. Micro (nano) plastics in wastewater: A critical review on toxicity risk assessment, behaviour, environmental impact and challenges. Chemosphere 2022, 290, 133169. [CrossRef] [PubMed]

214. Fakirov, S. A new approach to plastic recycling via the concept of microfibrillar composites. Adv. Ind. Eng. Polym. Res. 2021, 4, 187-198. [CrossRef]

215. Ronkay, F.; Molnar, B.; Gere, D.; Czigany, T. Plastic waste from marine environment: Demonstration of possible routes for recycling by different manufacturing technologies. Waste Manag. 2021, 119, 101-110. [CrossRef]

216. Shah, J.; Jan, M.R.; Zada, M. Effect of carbon supported metals on the tertiary recycling of waste expanded poly-styrene. Process Saf. Environ. Prot. 2015, 96, 149-155. [CrossRef]

217. Phillips, M.B.; Bonner, T.H. Occurrence and amount of microplastic ingested by fishes in watersheds of the Gulf of Mexico. Mar. Pollut. Bull. 2015, 100, 264-269. [CrossRef]

218. Ribeiro-Brasil, D.R.G.; Torres, N.R.; Picanço, A.B.; Sousa, D.S.; Ribeiro, V.S.; Brasil, L.S.; Montag, L.F.d.A. Contamination of stream fish by plastic waste in the Brazilian Amazon. Environ. Pollut. 2020, 266, 115241. [CrossRef]

219. Foley, C.J.; Feiner, Z.S.; Malinich, T.D.; Höök, T.O. A meta-analysis of the effects of exposure to microplastics on fish and aquatic invertebrates. Sci. Total Environ. 2018, 631, 550-559. [CrossRef]

220. Dawson, A.L.; Kawaguchi, S.; King, C.; Townsend, K.; King, R.; Huston, W.; Nash, S.B. Turning microplastics into nanoplastics through digestive fragmentation by Antarctic krill. Nat. Commun. 2018, 9, 1-8. [CrossRef]

221. Horton, A.A.; Barnes, D.K.A. Microplastic pollution in a rapidly changing world: Implications for remote and vulnerable marine ecosystems. Sci. Total Environ. 2020, 738, 140349. [CrossRef]

222. Borrelle, S.B.; Ringma, J.; Law, K.L.; Monnahan, C.C.; Lebreton, L.; McGivern, A.; Murphy, E.; Jambeck, J.; Leonard, G.H.; Hilleary, M.A.; et al. Predicted growth in plastic waste exceeds efforts to mitigate plastic pollution. Science 2020, 369, 1515-1518. [CrossRef]

223. Pillai, J. Managing plastic waste-What emerging economies like India can learn from developed nations. Reinf. Plast. 2021, 1-4. [CrossRef] 
224. Veerasingam, S.; Saha, M.; Suneel, V.; Vethamony, P.; Rodrigues, A.C.; Bhattacharyya, S.; Naik, B. Characteristics, seasonal distribution and surface degradation features of microplastic pellets along the Goa coast, India. ChemospheRe 2016, 159, 496-505. [CrossRef] [PubMed]

225. Liu, X.; Ma, C.; Wen, Y.; Chen, X.; Zhao, X.; Tang, T.; Holze, R.; Mijowska, E. Highly efficient conversion of waste plastic into thin carbon nanosheets for superior capacitive energy storage. Carbon 2021, 171, 819-828. [CrossRef]

226. Evode, N.; Qamar, S.A.; Bilal, M.; Barceló, D.; Iqbal, H.M.N. Plastic waste and its management strategies for environmental sustainability. Case Stud. Chem. Environ. Eng. 2021, 4, 100142. [CrossRef]

227. Phanisankar, B.; Rao, N.V.; Manikanta, J. Conversion of waste plastic to fuel products. Mater. Today Proc. 2020, $33,5190-5195$. [CrossRef]

228. Zhao, X.; Korey, M.; Li, K.; Copenhaver, K.; Tekinalp, H.; Celik, S.; Kalaitzidou, K.; Ruan, R.; Ragauskas, A.J.; Ozcan, S. Plastic waste upcycling toward a circular economy. Chem. Eng. J. 2022, 428, 131928. [CrossRef]

229. Jia, X.; Qin, C.; Friedberger, T.; Guan, Z.; Huang, Z. Efficient and selective degradation of polyethylenes into liquid fuels and waxes under mild conditions. Sci. Adv. 2016, 2, e1501591. [CrossRef]

230. Babayemi, J.O.; Nnorom, I.; Osibanjo, O.; Weber, R. Ensuring sustainability in plastics use in Africa: Consumption, waste generation, and projections. Environ. Sci. Eur. 2019, 31, 1-20. [CrossRef]

231. Amankwa, M.O.; Tetteh, E.K.; Mohale, G.T.; Dagba, G.; Opoku, P. The production of valuable products and fuel from plastic waste in Africa. Discov. Sustain. 2021, 2, 1-11. [CrossRef]

232. Eriksen, M.K.; Christiansen, J.D.; Daugaard, A.E.; Astrup, T.F. Closing the loop for PET, PE and PP waste from house-holds: Influence of material properties and product design for plastic recycling. Waste Manag. 2019, 96, 75-85. [CrossRef]

233. Armenise, S.; SyieLuing, W.; Ramírez-Velásquez, J.M.; Launay, F.; Wuebben, D.; Ngadi, N.; Muñoz, M. Plastic waste re-cycling via pyrolysis: A bibliometric survey and literature review. J. Anal. Appl. Pyrolysis 2021, 156, 105265. [CrossRef]

234. Tayeh, B.A.; Almeshal, I.; Magbool, H.M.; Alabduljabbar, H.; Alyousef, R. Performance of sustainable concrete containing different types of recycled plastic. J. Cleaner Prod. 2021, 328, 129517. [CrossRef]

235. Mehmandost, N.; Soriano, M.L.; Lucena, R.; Goudarzi, N.; Chamjangali, M.A.; Cardenas, S. Recycled polystyrene-cotton composites, giving a second life to plastic residues for environmental remediation. J. Environ. Chem. Eng. 2019, 7, 103424. [CrossRef]

236. Karmakar, G.P. Regeneration and Recovery of Plastics. Ref. Modul. Mater. Sci. Mater. Eng. 2020, 1-19. [CrossRef]

237. Vieira, O.; Ribeiro, R.S.; Diaz de Tuesta, J.L.; Gomes, H.T.; Silva, A.M.T. A systematic literature review on the conversion of plastic wastes into valuable 2D graphene-based materials. Chem. Eng. J. 2022, 428, 131399. [CrossRef]

238. Adamu, M.; Trabanpruek, P.; Jongvivatsakul, P.; Likitlersuang, S.; Iwanami, M. Mechanical performance and optimization of high-volume fly ash concrete containing plastic wastes and graphene nanoplatelets using response surface methodology. Constr. Build. Mater. 2021, 308, 125085. [CrossRef]

239. Mohan, H.T.; Jayanarayanan, K.; Mini, K. Recent trends in utilization of plastics waste composites as construction materials. Constr. Build. Mater. 2021, 271, 121520. [CrossRef]

240. Haque, M.S.; Islam, S. Effectiveness of waste plastic bottles as construction material in Rohingya displacement camps. Cleaner Eng. Technol. 2021, 3, 100110. [CrossRef]

241. Awoyera, P.O.; Adesina, A. Plastic wastes to construction products: Status, limitations and future perspective. Case Stud. Constr Mater. 2020, 12, e00330. [CrossRef]

242. Murts, G.T.; Ram, C.; Gebru, K.A. Fabrication and characterization of cement based floor tiles using eggshell and plastic wastes as a low cost construction materials. Case Stud. Constr. Mater. 2021, 15, e00747. [CrossRef]

243. Rajesh, S.; Murthy, Z.V.P. Ultrafiltration membranes from waste polyethylene terephthalate and additives: Synthesis and characterization. Química Nova 2014, 37, 653-657. [CrossRef]

244. Kusumocahyo, S.P.; Ambani, S.K.; Kusumadewi, S.; Sutanto, H.; Widiputri, D.I.; Kartawiria, I.S. Utilization of used polyethylene terephthalate (PET) bottles for the development of ultrafiltration membrane. J. Environ. Chem. Eng. 2020, 8, 104381. [CrossRef]

245. Maiti, A.; Pandey, A. Polymer and Waste Plastic in Membranes. Ref. Modul. Mater. Sci. Mater. Eng. 2021. [CrossRef]

246. Tao, Y.; Liu, M.; Han, W.; Li, P. Waste office paper filled polylactic acid composite filaments for 3D printing. Compos. Part B Eng. 2021, 221, 108998. [CrossRef]

247. Garrido, J.; Sáez, J.; Armesto, J.I.; Espada, A.M.; Silva, D.; Goikoetxea, J.; Lekube, B. 3D printing as an enabling technology to implement maritime plastic Circular Economy. Procedia Manuf. 2020, 51, 635-641. [CrossRef]

248. Santander, P.; Cruz Sanchez, F.A.; Boudaoud, H.; Camargo, M. Closed loop supply chain network for local and distributed plastic recycling for 3D printing: A MILP-based optimization approach. Resour. Conserv. Recycl. 2020, 154, 104531. [CrossRef]

249. Maldonado-García, B.; Pal, A.K.; Misra, M.; Gregori, S.; Mohanty, A.K. Sustainable 3D printed composites from recycled ocean plastics and pyrolyzed soy-hulls: Optimization of printing parameters, performance studies and prototypes development. Compos. Part C Open Access 2021, 6, 100197. [CrossRef]

250. Choudhary, A.K.; Jha, J.N.; Gill, K.S. Utilization of Plastic Wastes for Improving the Sub-Grades in Flexible Pavements. Paving Mater. Pavement Anal. 2010, 320-326. [CrossRef]

251. Choudhary, A.K.; Jha, J.N.; Gill, K.S.; Shukla, S.K. Utilization of Fly Ash and Waste Recycled Product Reinforced with Plastic Wastes as Construction Materials in Flexible Pavement. In Geo-Congress 2014 Technical Papers, Atlanta, Georgia, 23-26 February 2014; American Society of Civil Engineers (ASCE): Reston, VA, USA, 2014; p. 3890. 
252. Benson, C.H.; Khire, M.V. Reinforcing Sand with Strips of Reclaimed High-Density Polyethylene. J. Geotech. Eng. 1994, 120, 838-855. [CrossRef]

253. Kumi-Larbi, A.; Yunana, D.; Kamsouloum, P.; Webster, M.; Wilson, D.C.; Cheeseman, C. Recycling waste plastics in de-veloping countries: Use of low-density polyethylene water sachets to form plastic bonded sand blocks. Waste Manag. 2018, 80, 112-118. [CrossRef]

254. Xiao, D.; Yu, Z.; Qing, S.; Du, S.; Xiao, H. Development of agricultural waste/recycled plastic/waste oil bio-composite wallpaper based on two-phase dye and liquefaction filling technology. Environ. Sci. Pollut. Res. 2020, 27, 2599-2621. [CrossRef]

255. Galati, A.; Scalenghe, R. Plastic end-of-life alternatives, with a focus on the agricultural sector. Curr. Opin. Chem. Eng. 2021, 32, 100681. [CrossRef]

256. Lichtenhan, J.D.; Pielichowski, K.; Blanco, I. POSS-Based Polymers. Polymers 2019, 11, 1727. [CrossRef]

257. Pegoretti, A.; Kolarik, J.; Peroni, C.; Migliaresi, C. Recycled poly(ethylene terephthalate)/layered silicate nanocomposites: Morphology and tensile mechanical properties. Polymers 2004, 45, 2751-2759. [CrossRef]

258. Kráčalík, M.; Pospíšil, L.; Šlouf, M.; Mikešová, J.; Sikora, A.; Šimoník, J.; Fortelný, I. Recycled poly(ethylene terephthalate) reinforced with basalt fibres: Rheology, structure, and utility properties. Polym. Compos. 2008, 29, 437-442. [CrossRef]

259. Velenturf, A.P.; Purnell, P. Principles for a sustainable circular economy. Sustain. Prod. Consum. 2021, 27, 1437-1457. [CrossRef]

260. Bening, C.R.; Pruess, J.T.; Blum, N.U. Towards a circular plastics economy: Interacting barriers and con-tested solutions for flexible packaging recycling. J. Clean. Prod. 2021, 302, 126966. [CrossRef]

261. Johansen, M.R.; Christensen, T.B.; Ramos, T.M.; Syberg, K. A review of the plastic value chain from a circular economy perspective. J. Environ. Manag. 2022, 302, 113975. [CrossRef]

262. Kirchherr, J.; Reike, D.; Hekkert, M. Conceptualizing the circular economy: An analysis of 114 definitions. Resour. Conserv. Recycl. 2017, 127, 221-232. [CrossRef]

263. Gall, M.; Wiener, M.; de Oliveira, C.C.; Lang, R.W.; Hansen, E.G. Building a circular plastics economy with informal waste pickers: Recyclate quality, business model, and societal impacts. Resour. Conserv. Recycl. 2020, 156, 104685. [CrossRef]

264. Bucknall, D.G. Plastics as a materials system in a circular economy. Philos. Trans. R Soc. A Math. Phys. Eng. Sci. 2020, 378,20190268 [CrossRef] [PubMed]

265. Valerio, O.; Muthuraj, R.; Codou, A. Strategies for polymer to polymer recycling from waste: Current trends and op-portunities for improving the circular economy of polymers in South America. Curr. Opin. Green Sustain. Chem. 2020, 25, 100381. [CrossRef]

266. Delvere, I.; Iltina, M.; Shanbayev, M.; Abildayeva, A.; Kuzhamberdieva, S.; Blumberga, D. Evaluation of Polymer Matrix Composite Waste Recycling Methods. Environ. Clim. Technol. 2019, 23, 168-187. [CrossRef]

267. Singh, A.K.; Bedi, R.; Kaith, B.S. Composite materials based on recycled polyethylene terephthalate and their properties-A comprehensive review. Compos. Part B Eng. 2021, 219, 108928. [CrossRef]

268. Velasquez, E.; Garrido, L.; Guarda, A.; Galotto, M.; de Dicastillo, C.L. Increasing the incorporation of recycled PET on polymeric blends through the reinforcement with commercial nanoclays. Appl. Clay Sci. 2019, 180, 105185. [CrossRef]

269. Cosnita, M.; Cazan, C.; Duta, A. The influence of inorganic additive on the water stability and mechanical properties of recycled rubber, polyethylene terephthalate, high density polyethylene and wood composites. J. Clean. Prod. 2017, 165, 630-636. [CrossRef]

270. Kakoria, A.; Chandel, S.S.; Sinha-Ray, S. Novel supersonically solution blown nanofibers from waste PET bottle for PM0.1-2 filtration: From waste to pollution mitigation. Polymers 2021, 234, 124260. [CrossRef]

271. Xu, A.; Wang, Y.; Xu, X.; Xiao, Z.; Liu, R. A Clean and Sustainable Cellulose-Based Composite Film Reinforced with Waste Plastic Polyethylene Terephthalate. Adv. Mater. Sci. Eng. 2020, 2020, 1-7. [CrossRef]

272. Aydoğmuş, E.; Arslanoğlu, H.; Dağ, M. Production of waste polyethylene terephthalate reinforced biocomposite with RSM design and evaluation of thermophysical properties. J. Build. Eng. 2021, 44, 103337. [CrossRef]

273. US EPA, Advancing Sustainable Materials Management: Facts and Figures 2013: Assessing Trends in Material Generation, Recycling and Disposal in the United States. Available online: https:/ /www.epa.gov/sites/production/files/2021-01/documents/20 18_tables_and_figures_dec_2020_fnl_508.pdf (accessed on 9 November 2021).

274. Pasternak, G.; Ormeno-Cano, N.; Rutkowski, P. Recycled waste polypropylene composite ceramic membranes for ex-tended lifetime of microbial fuel cells. Chem. Eng. J. 2021, 425, 130707. [CrossRef]

275. Sezgin, H.; Kucukali-Ozturk, M.; Berkalp, O.B.; Yalcin-Enis, I. Design of composite insulation panels containing $100 \%$ recycled cotton fibers and polyethylene/polypropylene packaging wastes. J. Clean. Prod. 2021, 304, 127132. [CrossRef]

276. Martínez-López, M.; Martínez-Barrera, G.; Salgado-Delgado, R.; Gencel, O. Recycling polypropylene and polyethylene wastes in production of polyester based polymer mortars. Constr. Build. Mater. 2021, 274, 121487. [CrossRef]

277. Lin, A.; Tan, Y.K.; Wang, C.-H.; Kua, H.W.; Taylor, H. Utilization of waste materials in a novel mortar-polymer laminar composite to be applied in construction 3D-printing. Compos. Struct. 2020, 253, 112764. [CrossRef]

278. Sun, Z.; Shen, Z.; Zhang, X.; Ma, S. Co-recycling of acrylonitrile-butadiene-styrene waste plastic and nonmetal particles from waste printed circuit boards to manufacture reproduction composites. Environ. Technol. 2015, 36, 160-168. [CrossRef] [PubMed]

279. Zulkernain, N.H.; Gani, P.; Chuck Chuan, N.; Uvarajan, T. Utilisation of plastic waste as aggregate in construction materials: A review. Constr. Build. Mater. 2021, 296, 123669. [CrossRef]

280. Safarpour, M.; Safikhani, A.; Vatanpour, V. Polyvinyl chloride-based membranes: A review on fabrication techniques, applications and future perspectives. Sep. Purif. Technol. 2021, 279, 119678. [CrossRef] 
281. Mohammed, A.A.; Mohammed, I.I.; Mohammed, S.A. Some properties of concrete with plastic aggregate derived from shredded PVC sheets. Constr. Build. Mater. 2019, 201, 232-245. [CrossRef]

282. Xu, X.; Zhu, D.; Wang, X.; Deng, L.; Fan, X.; Ding, Z.; Makinia, J. Transformation of polyvinyl chloride (PVC) into a versatile and efficient adsorbent of $\mathrm{Cu}(\mathrm{II})$ cations and $\mathrm{Cr}(\mathrm{VI})$ anions through hydrothermal treatment and sulfonation. J. Hazard. Mater. 2022, 423, 126973. [CrossRef]

283. Bhran, A.; Shoaib, A.; Elsadeq, D.; El-Gendi, A.; Abdallah, H. Preparation of PVC/PVP composite polymer membranes via phase inversion process for water treatment purposes. Chin. J. Chem. Eng. 2018, 26, 715-722. [CrossRef]

284. Hezarjaribi, M.; Bakeri, G.; Sillanpää, M.; Chaichi, M.J.; Akbari, S.; Rahimpour, A. Novel adsorptive PVC nanofibrous/thiolfunctionalized TNT composite UF membranes for effective dynamic removal of heavy metal ions. J. Environ. Manag. 2021, 284, 111996. [CrossRef]

285. Yong, M.; Zhang, Y.; Sun, S.; Liu, W. Properties of polyvinyl chloride (PVC) ultrafiltration membrane improved by lignin: Hydrophilicity and antifouling. J. Membr. Sci. 2019, 575, 50-59. [CrossRef]

286. Aji, M.M.; Narendren, S.; Purkait, M.K.; Katiyar, V. Utilization of waste polyvinyl chloride (PVC) for ultrafiltration membrane fabrication and its characterization. J. Environ. Chem. Eng. 2020, 8, 103650. [CrossRef]

287. Turner, A. Polystyrene foam as a source and sink of chemicals in the marine environment: An XRF study. Chemosphere 2021, 263, 128087. [CrossRef] [PubMed]

288. Gao, C.; Shi, Y.; Chen, Y.; Zhu, S.; Feng, Y.; Lv, Y.; Yang, F.; Liu, M.; Shui, W. Constructing segregated polystyrene composites for excellent fire resistance and electromagnetic wave shielding. J. Colloid Interface Sci. 2022, 606, 1193-1204. [CrossRef] [PubMed]

289. Eskander, S.B.; Saleh, H.M.; Tawfik, M.E.; Bayoumi, T.A. Towards potential applications of cement-polymer composites based on recycled polystyrene foam wastes on construction fields: Impact of exposure to water ecologies. Case Stud. Constr. Mater. 2021, 15, e00664. [CrossRef]

290. Saleh, H.M.; Eskander, S.B. Impact of water flooding on hard cement-recycled polystyrene composite immobilizing ra-dioactive sulfate waste simulate. Constr. Build. Mater. 2019, 222, 522-530. [CrossRef]

291. Maaroufi, M.; Belarbi, R.; Abahri, K.; Benmahiddine, F. Full characterization of hygrothermal, mechanical and morpho-logical properties of a recycled expanded polystyrene-based mortar. Constr. Build. Mater. 2021, 301, 124310. [CrossRef]

292. Bouzit, S.; Merli, F.; Sonebi, M.; Buratti, C.; Taha, M. Gypsum-plasters mixed with polystyrene balls for building insula-tion: Experimental characterization and energy performance. Constr. Build. Mater. 2021, 283, 122625. [CrossRef]

293. Olofinnade, O.; Chandra, S.; Chakraborty, P. Recycling of high impact polystyrene and low-density polyethylene plastic wastes in lightweight based concrete for sustainable construction. In Proceedings of the International Conference \& Exposition on Mechanical, Material and Manufacturing Technology (ICE3MT), Hyderabad, India, 9 October 2020; pp. 2151-2156. [CrossRef]

294. Sow, P.K.; Ishita; Singhal, R. Sustainable approach to recycle waste polystyrene to high-value submicron fibers using so-lution blow spinning and application towards oil-water separation. J. Environ. Chem. Eng. 2020, 8, 102786. [CrossRef]

295. Machado, N.C.; de Jesus, L.A.; Pinto, P.S.; de Paula, F.G.; Alves, M.O.; Mendes, K.H.; Mambrini, R.V.; Barrreda, D.; Rocha, V.; Santamaría, R.; et al. Waste-polystyrene foams-derived magnetic carbon material for adsorption and redox supercapacitor applications. J. Clean. Prod. 2021, 313, 127903. [CrossRef]

296. Reynoso, L.E.; Carrizo Romero, Á.B.; Viegas, G.M.; San Juan, G.A. Characterization of an alternative thermal insulation material using recycled expanded polystyrene. Constr. Build. Mater. 2021, 301, 124058. [CrossRef]

297. Thakur, S.; Verma, A.; Sharma, B.; Chaudhary, J.; Tamulevicius, S.; Thakur, V.K. Recent developments in recycling of polystyrene based plastics. Curr. Opin. Green Sustain. Chem. 2018, 13, 32-38. [CrossRef]

298. Lens-Pechakova, L.S. Recent studies on enzyme-catalysed recycling and biodegradation of synthetic polymers. Adv. Ind. Eng. Polym. Res. 2021, 4, 151-158. [CrossRef]

299. Dhakshinamoorthy, A.; Jacob, M.; Vignesh, N.S.; Varalakshmi, P. Pristine and modified chitosan as solid catalysts for catalysis and biodiesel production: A minireview. Int. J. Biol. Macromol. 2021, 167, 807-833. [CrossRef] [PubMed]

300. Goyal, D.; Renu Hada, P.; Anita Bhatia, S.K.; Malpani, S.K. Development of green, effective, and cost-efficient perlite supported solid base catalyst and application in condensation reac-tions. Mater. Today Proc. 2021. Available online: https://www. sciencedirect.com/science/article/pii/S2214785321066232 (accessed on 7 November 2021). [CrossRef]

301. Mandari, V.; Devarai, S.K. Biodiesel Production Using Homogeneous, Heterogeneous, and Enzyme Catalysts via Transesterification and Esterification Reactions: A Critical Review. Bioenergy Res. 2021, 1-27. [CrossRef]

302. Guan, Y.; Chaffart, D.; Liu, G.; Tan, Z.; Zhang, D.; Wang, Y.; Li, J.; Ricardez-Sandoval, L. Machine learning in solid heterogeneous catalysis: Recent developments, challenges and perspectives. Chem. Eng. Sci. 2021, 248, 117224. [CrossRef]

303. Sedghi, R.; Asadi, S.; Heidari, B.; Heravi, M.M. $\mathrm{TiO}_{2}$ / polymeric supported silver nanoparticles applied as superior nano-catalyst in reduction reactions. Mater. Res. Bull. 2017, 92, 65-73. [CrossRef]

304. Nasrollahzadeh, M.; Sajjadi, M.; Shokouhimehr, M.; Varma, R.S. Recent developments in palladium (nano)catalysts supported on polymers for selective and sustainable oxidation processes. Coord. Chem. Rev. 2019, 397, 54-75. [CrossRef]

305. Van Deelen, T.W.; Hernández Mejía, C.; De Jong, K.P. Control of metal-support interactions in heterogeneous catalysts to enhance activity and selectivity. Nat. Catal. 2019, 2, 955-970. [CrossRef]

306. Sandhu, S.; Krishnan, S.; Karim, A.V.; Shriwastav, A. Photocatalytic Denitrification of Water using Polystyrene Immobilized TiO 2 as Floating Catalyst. J. Environ. Chem. Eng. 2020, 8, 104471. [CrossRef] 
307. Sboui, M.; Nsib, M.F.; Rayes, A.; Swaminathan, M.; Houas, $\mathrm{A}$. $\mathrm{TiO}_{2}-\mathrm{PANI} /$ Cork composite: A new floating photocatalyst for the treatment of organic pollutants under sunlight irradiation. J. Environ. Sci. 2017, 60, 3-13. [CrossRef]

308. Zhao, X.; Zhang, Y.; Pan, S.; Zhang, X.; Zhang, W.; Pan, B. Utilization of gel-type polystyrene host for immobilization of nanosized hydrated zirconium oxides: A new strategy for enhanced phosphate removal. Chemosphere 2021, 263, 127938. [CrossRef] [PubMed]

309. Perera, M.K.; Englehardt, J.D.; Dvorak, A.C. Technologies for Recovering Nutrients from Wastewater: A Critical Review. Environ. Eng. Sci. 2019, 36, 1-19. [CrossRef]

310. Patel, S.B.; Vasava, D.V. Azo functionalized polystyrene supported Copper nanoparticles: An economical and highly efficient catalyst for A3 and KA2 coupling reaction under microwave irradiation. Nano Struct. Nano Objects 2020, 21, 100416. [CrossRef]

311. Sandoval, C.; Molina, G.; Vargas Jentzsch, P.; Pérez, J.; Muñoz, F. Photocatalytic Degradation of Azo Dyes Over Semi-conductors Supported on Polyethylene Terephthalate and Polystyrene Substrates. J. Adv. Oxid. Technol. 2017, 20, 1-19.

312. Mossmann, A.; Dotto, G.L.; Hotza, D.; Jahn, S.L.; Foletto, E.L. Preparation of polyethylene-supported zero-valent iron buoyant catalyst and its performance for Ponceau 4R decolorization by photo-Fenton process. J. Environ. Chem. Eng. 2019, 7, 102963. [CrossRef]

313. Thiam, A.; Brillas, E.; Garrido, J.A.; Rodríguez, R.M.; Sirés, I. Routes for the electrochemical degradation of the artificial food azo-colour Ponceau 4R by advanced oxidation processes. Appl. Catal. B Environ. 2016, 180, 227-236. [CrossRef]

314. Linda, T.; Muthupoongodi, S.; Sahaya Shajan, X.; Balakumar, S. Photocatalytic Degradation of Congo Red and Crystal Violet Dyes on Cellulose/PVC/ZnO Composites under UV Light Irradiation. Mater. Today Proc. 2016, 3, 2035-2041. [CrossRef]

315. Bartáček, J.; Drabina, P.; Váňa, J.; Sedlák, M. Recoverable polystyrene-supported catalysts for Sharpless allylic alcohols epoxidations. React. Funct. Polym. 2019, 137, 123-132. [CrossRef]

316. Vaiano, V.; Chianese, L.; Rizzo, L.; Iervolino, G. Visible light driven oxidation of arsenite to arsenate in aqueous solution using Cu-doped ZnO supported on polystyrene pellets. Catal. Today 2021, 361, 69-76. [CrossRef]

317. Wang, J.-C.; Li, Y.; Li, H.; Cui, Z.-H.; Hou, Y.; Shi, W.; Zhang, Y.-P. A novel synthesis of oleophylic $\mathrm{Fe}_{2} \mathrm{O}_{3} / \mathrm{polystyrene} \mathrm{fibers}$ by $\gamma$-Ray irradiation for the enhanced photocatalysis of 4-chlorophenol and 4-nitrophenol degradation. J. Hazard. Mater. 2019, 379, 120806. [CrossRef] [PubMed]

318. Ayeleru, O.O.; Dlova, S.; Akinribide, O.J.; Ntuli, F.; Kupolati, W.K.; Marina, P.F.; Blencowe, A.; Olubambi, P.A. Challenges of plastic waste generation and management in sub-Saharan Africa: A review. Waste Manag. 2020, 110, 24-42. [CrossRef]

319. Jiang, J.; Shi, K.; Zhang, X.; Yu, K.; Zhang, H.; He, J.; Ju, Y.; Liu, J. From plastic waste to wealth using chemical recycling: A review. J. Environ. Chem. Eng. 2022, 10, 106867. [CrossRef]

320. Selvaranjan, K.; Navaratnam, S.; Rajeev, P.; Ravintherakumaran, N. Environmental challenges induced by extensive use of face masks during COVID-19: A review and potential solutions. Environ. Chall. 2021, 3, 100039. [CrossRef]

321. Yaradoddi, J.S.; Banapurmath, N.R.; Ganachari, S.V.; Soudagar, M.E.M.; Mubarak, N.M.; Hallad, S.; Fayaz, H. Bio-degradable carboxymethyl cellulose based material for sustainable packaging application. Sci. Reports. 2020, 10, 21960. 